\title{
PRIVATE INFORMATION, EARNINGS MANIPULATIONS, AND EXECUTIVE STOCK OPTION EXERCISES
}

\author{
Eli Bartov \\ Leonard N. Stern School of Business \\ New York University \\ 44 W. $4^{\text {th }}$ St., Suite $10-94$ \\ New York, NY 10012 \\ ebartov@stern.nyu.edu \\ Partha Mohanram \\ Columbia Business School \\ Columbia University \\ 605-A Uris Hall, 3022 Broadway \\ New York, NY 10027 \\ pm2128@columbia.edu
}

April 2004

We acknowledge helpful comments from Jennifer Carpenter, Jim Ohlson, two anonymous reviewers, participants at the Baruch-Columbia-NYU-Rutgers annual conference, and workshop participants at City University-Hong Kong, Cornell University, Florida State University, Hebrew University, and New York University (Finance Seminar). 


\title{
PRIVATE INFORMATION, EARNINGS MANIPULATIONS, AND EXECUTIVE STOCK OPTION EXERCISES
}

\begin{abstract}
This paper investigates the decision by top-level executives of more than 1,200 public corporations to exercise large stock option awards in the period 1992-2001. We hypothesize and find that abnormally large option exercises predict stock return future performance. We then hypothesize that this predictive ability represents private information about disappointing earnings in the post-exercise period. Consistent with this hypothesis we find that abnormally positive earnings performance in the pre-exercise period turns to disappointing earnings performance in the post-exercise period, and that this pattern comes as a surprise to even sophisticated market participants (financial analysts). We also hypothesize and find that the disappointing earnings in the post-exercise period represent a reversal of inflated earnings in the pre-exercise period. Collectively, these findings suggest that the private information used by top-level executives to time abnormally large exercises follows from earnings management so as to increase the cash payout of exercises.
\end{abstract}

Key words: Executive compensation; Incentives, Stock option exercises; Earnings management.

Data Availability: All data are commercially available from sources outlined in the text. 


\section{PRIVATE INFORMATION, EARNINGS MANIPULATIONS, AND EXECUTIVE STOCK OPTION EXERCISES}

\section{INTRODUCTION}

In the last two decades, as stock-option awards to employees of publicly traded US corporations have become increasingly popular, many studies have investigated a variety of aspects of these options. Most of these studies have focused on awards to top management rather than to a firm's entire workforce because theory suggests that stock option awards are best used to motivate only employees with clear control over firm performance and value.

One strand of this literature has examined whether stock-option awards induce opportunistic managerial behavior. One type of finding from this literature shows that CEOs receive stock-option grants shortly before the release of favorable quarterly earnings news (Yermack 1997) and favorable voluntary news (Aboody and Kasznick 2000). These findings suggest CEOs opportunistically time the option-grant date (Yermack 1997) or disclosures around it (Aboody and Kasznick 2000) to increase the value of their stock-option compensation.

Another type of finding from this literature, which concerns the ability of top-level executives to time the exercises of their stock options, documents conflicting results. Using a sample of all option exercises by corporate insiders, Carpenter and Remmers (2001, p. 515) find little evidence of such timing in the 1990s, and conclude that in that period exercises are driven primarily by diversification or liquidity needs. Conversely, Huddart and Lang (2003) using a proprietary sample of exercise decisions of over 50,000 employees at seven firms find that the timing when both top managers and junior employees exercise their stock options can be used to predict future stock returns. Assuming a semi-strong capital market, they conclude that employees of all levels (partially) base their exercise decisions on private information.

The purpose of our study is twofold. First, given these conflicting findings about the 
ability of top-level executives to time stock-option exercises, we develop potentially more powerful tests that will help determine whether such timing ability exits. The increased power follows from our research-design choice to focus on abnormally large exercises, where the incentives for private-information-based exercise are greatest. ${ }^{1}$

Using a ten-year sample period, 1992-2001, we document reversals in stock price changes around the year in which abnormally large exercises by top-level executives occur (the exercise year). Specifically, stock price changes are abnormally positive in the pre-exercise period and abnormally negative in the post-exercise period. In addition, we repeat these tests using Carpenter and Remmers' (2001) sample period (i.e. 1992-1995) and sample selection criteria (i.e., including all exercises available from EXECUCOMP). Like them, we find no evidence of stock price reversals in the post-exercise period. These findings are consistent with the hypothesis that top-level executives use private information to time abnormally large exercises, where the benefits from such timing are largest.

The second and more important purpose of our study is to investigate the nature of the private information used by executives to time exercises. Unlike prior research, our investigation attempts to provide a direct link between large option exercise decisions and private information. It poses two hypotheses. The first hypothesize asserts that the timing of exercises by top management reflects private information about future earnings. The intuition underlying this hypothesis is that as earnings news and stock price changes are positively related (see, e.g., Ball and Brown 1968), managers with private information about disappointing future earnings will exercise stock-options exercises and sell the shares acquired through exercises prior to the earnings realization.

Consistent with this hypothesis, we find that in the pre-exercise period annual earnings

\footnotetext{
${ }^{1}$ Given this focus, our conclusions apply to large executive option exercises, not necessarily to all exercises.
} 
changes are abnormally positive, with the opposite holding for the post-exercise period. Furthermore, findings from errors in analyst earnings forecasts indicate that financial analysts do not anticipate the superior earnings performance in the pre-exercise period, nor do they predict the inferior earnings performance in the post-exercise-year period. These last findings provide further evidence consistent with the observed earnings patterns representing private information held by top-level executives, as even sophisticated market participants (financial analysts) are unable to decipher this information at the time of exercise.

Are these observed patterns in earnings performance associated with exogenous events (e.g., an increase/decrease in the demand for a firm's products or services) or with a firm's predictable reporting strategy (e.g., a reversal of previously reported inflated earnings)? The computation of earnings involves significant managerial discretion which investors may be unable to undo due to information asymmetry between a firm's insiders and outsiders. Given this, and given that earnings news and equity values are positively related, inflating income in the pre-exercise period can potentially be both a feasible and effective means to increase the cash payout from option exercises. Our second hypothesis thus tests whether top-level executives inflate earnings prior to large stock-option exercises.

We find that in the pre-exercise period discretionary accruals, but not non-discretionary accruals, are abnormally high, and that these abnormally high discretionary accruals underlie the observed abnormally positive earnings performance during the pre-exercise period discussed above. These findings are consistent with our hypothesis that in an effort to increase the cash payout from option exercises and sales of acquired shares, managers inflate earnings through accruals management in the period leading up to the abnormally large exercises. The results also indicate that discretionary accruals, but not non-discretionary accruals, reverse in the post- 
exercise period. This evidence is further consistent with the hypothesis that managers inflate earnings prior to exercises.

Our findings contribute to the literature in two ways. First, we highlight that in the 1990s abnormally large exercises by executives precede significantly negative (annual) abnormal stock returns, consistent with the use of private information to time exercises. The contribution follows because prior research investigating this question reports conflicting results. While Carpenter and Remmers (2001, p. 514) report, "we find little evidence of use of inside information to time exercises since the removal of the holding restriction in May of 1991," Huddart and Lang (2003, p. 4) assert, “...exercise activity predicts stock returns mainly over the three months after the exercise decision."

Second, and more importantly, we shed light into the nature of the private information used by executives to time exercises. Specifically, our results are consistent with managers having private information about disappointing future earnings due to reversals of inflated earnings in the pre-exercise period. These findings are important because they point to a potential limitation associated with executive stock options not considered by theory (Jensen and Meckling 1976) and corporate executives (see, The Wall Street Journal 2003a) ${ }^{2}$ advocating their use.

The next section reviews prior research. Section 3 discusses our major research design choices, defines the variables, outlines the sample selection procedure, and describes the data. Section 4 delineates the tests and reports the results, and the final section summarizes our findings, conclusions, and study limitations.

\footnotetext{
${ }^{2}$ The Wall Street Journal (2003a) reports that the chief financial officer of Station Casinos Inc. justified generous executive stock option awards in his company by saying, "We're trying to align our interests as executives with those of the shareholders."
} 


\section{PRIOR RESEARCH}

The structure of executive compensation schemes has changed over the last two decades. In an effort to better align the interest of shareholders and management and thereby alleviate agency costs (Jensen and Meckling 1976), boards of directors have dramatically increased the stock option awards to top-level executives (see, e.g., Yermack 1995, Lakonishok and Lee 2001, and Balsam 2002). As the popularity of executive stock options has grown, so has the attention paid to them by researchers.

One strand of the academic literature has investigated whether executive stock options help in aligning incentives. Hanlon et al. (2003) find that top 5 executive stock option grants are positively associated with future operating income--a one-dollar increase in executive stock option grant due to economic factors is associated with a first order increase of $\$ 3.97$ in future earnings. They also find that the association between executive stock option grants and future income is driven primarily by economic determinants and not by poor governance quality. Rajgopal and Shevlin (2002) find that in the oil and gas industry, CEO stock options help align the interests of risk-neutral shareholders and risk-averse managers, thereby mitigating the problem of CEOs passing up risky yet positive net present value exploration projects. Balsam and Miharjo (2003) show that executive stock options affect executive retention; the more stock options an executive has the less likely he/she will leave in the succeeding year. Finally, Core and Guay (1999) find that, consistent with economic theory, firms actively manage grants of new equity incentives to CEOs in response to deviations from an optimal level of equity incentives.

Other studies have examined whether stock-option compensation schemes induce opportunistic managerial behavior. Yermack (1997) examines 620 stock options awards to CEOs of Fortune 500 companies between 1992 and 1994. He hypothesizes that CEOs 
opportunistically time option-grant dates around earnings announcements to increase their compensation. If so, favorable earnings announcements should occur after stock option awards are made and adverse announcements before they are made. Consistent with this hypothesis, Yermack documents that awards are timed to coincide with favorable movements in firm stock prices; abnormal stock returns around earnings announcements following CEOs' option grants are more favorable than those around announcements preceding option grants. Data from earnings surprises provide further evidence consistent with this hypothesis; positive surprises are more likely to occur when earnings are announced after option awards, with the opposite holding for announcements preceding option awards. In addition, Aboody and Kasznick (2000) study a sample of 2,039 stock option awards in the period 1992-1996 to CEOs of 572 firms with a fixed award schedule. They hypothesize that CEOs time their voluntary disclosures around dates of fixed award schedules to increase their stock option compensation. Consistent with this hypothesis, they find that earnings forecasts issued during the three months prior to scheduled awards are significantly less optimistically biased than those issued for the same firms in other months. They also find that scheduled grant dates are followed by significant positive abnormal returns. Both Yermack (1997) and Aboody and Kasznick (2000) investigate executives' opportunistic behavior around stock-option grants; one way in which we complement this line of research is by investigating managerial behavior around (large) option exercises.

Prior studies have also examined the extent to which insider trading is informative, with mixed results. On the one hand, studies have shown that insiders are better informed and earn abnormal returns (see, e.g., Jaffe 1974, Seyhun 1998), as well as that they sell on foreknowledge of forthcoming earnings declines as long as two years before the decline is reported (Ke, Huddart and Petroni 2003). Furthermore, Beneish (1999) shows that managers of firms with inflated 
earnings are more likely to sell their holdings and exercise stock appreciation rights than managers in control firms. Beneish and Vargus (2002) find evidence consistent with insiders trading on their knowledge of factors associated with accrual persistence, while Beneish, Press, and Vargus (2003) document that upwards earnings management occurs in firms facing higher than expected costs of default, and that insider selling and debt-covenant incentives co-exist and are complementary. On the other hand, Lakonishok and Lee (2001), who investigate insider trading activities of all companies traded on the NYSE, AMEX, and NASDAQ during 19751995, conclude that the informativeness of insider trading is attributable to purchases of insiders in small firms, and that insider selling has no predictive ability.

Another strand of this literature examines the ability of top-level executives to time stock-option exercises. This research also yields mixed results. Carpenter and Remmers (2001) investigate whether corporate insiders use private information to time the exercises of their executive stock options. Their sample covers two periods, 1984-1990 and 1992-1995, and includes all reported insider exercises in these periods. ${ }^{3}$ They find that exercises from their early sample period, the one in which insiders had to hold the stock acquired through option exercise for six months, precede significantly positive abnormal (i.e., size- and momentum-adjusted) stock return performance, suggesting the use of private information to time exercises. However, they find little evidence of negative abnormal stock returns after option exercise in the later sample period, in which insiders are able to sell acquired stock immediately, providing little support for the hypothesis that executives use private information to time exercises in the new

\footnotetext{
${ }^{3}$ Year 1991 is excluded from the sample due to a change in the regulatory environment surrounding stock option exercises that became effective in May 1991. In May 1991, the Securities and Exchange Commission (SEC) changed the starting date of the six-month holding period--required by the Securities Exchange Act's Section 16(b)-from the option's exercise date to its grant date. This change enables insiders to sell stock acquired through option exercise immediately as the structure of virtually all option plans is such that the first opportunity to exercise the options is more than six months after granting.
} 
regulatory regime. Conversely, Huddart and Lang (2003), using a proprietary sample of exercise decisions of over 50,000 employees at seven firms, find that the timing when both top management and junior employees exercise their stock options can be used to predict future market-adjusted stock returns. Assuming a semi-strong capital market, they interpret these findings as evidence that employees of all levels (partially) base their exercise decisions on private information. However, this interpretation is clouded by findings in Core and Guay (2001, Table 8) showing no correlation between option exercises by non-executives in year $t$ and raw stock returns in year $t+1$, for a sample of 1,263 firm-years from 1995 to 1997 ; their conclusion, "We find no evidence that option exercises by non-executives reflect private information about future returns."

Our study contributes to this strand of research in two ways. First, given the conflicting findings on the ability of top-level executives to time stock-option exercises, we develop potentially more powerful tests that help determine whether executives time option exercises, by focusing on abnormally large exercises where the incentives to time exercises are greatest, and thus easier to detect if it exists. ${ }^{4}$ Second, unlike prior studies that are unable to identify the type of private information used to time exercises (see, e.g. Huddart and Lang 2003, p. 7), we present evidence consistent with top-level managers using private information about future earnings to time exercises. We further present evidence consistent with even sophisticated investors being unable to decipher this information at the time of the exercises. These findings help provide a direct link between option exercise decisions and private information, which increases confidence in the validity of our findings.

\footnotetext{
${ }^{4}$ Our findings do not necessarily generalize to option exercises by non-executive employees, as it is arguable that price-relevant information is concentrated in the hands of top executives.
} 
Finally, the accounting literature has also examined the impact of earnings management on compensation. Healy (1985) shows that managers manipulate earnings to increase their bonuses. Balsam (1998) demonstrates that managers increase their cash bonuses through the judicious use of discretionary accruals, and Balsam et al. (2003) show that firms providing high levels of stock option compensation relative to performance allocate smaller portion of the options' value to the pro-forma expense, apparently to reduce criticism of that compensation. ${ }^{5}$ Cheng and Warfield (2003) find that the incidence of reported earnings that meet or just beat analyst earnings forecasts is significantly higher for firms with higher stock-based compensation. They also document a positive association between the magnitude of discretionary accruals and the magnitude of stock-based compensation, and lower association between earnings and stock returns for firms with high stock-based compensation. Based on these findings Cheng and Warfield conclude that stock-based compensation is associated with increased use of discretionary accruals to meet or just beat analysts' forecasts, leading to less informative earnings. Finally, Henry (2003) regresses discretionary accruals in quarter $t$ on option grants and option exercises in a thirty-day period following the release date of quarter $t$ earnings and finds that grants are negatively related to discretionary accruals and option exercises are positively related to discretionary accruals. Our contribution to this literature follows because our evidence is consistent with managers opportunistically inflating accruals and thus earnings prior to exercises in an effort to increase cash payout from the exercises, and this comes at the expense of future earnings when the accruals reverse.

\footnotetext{
${ }^{5}$ Compensation experts seem to agree that managers manipulate earnings to maximize compensation. For example, according to The Wall Street Journal (2003d), Mr. Wamberg, a compensation consultant, said that investors should applaud GE's use of a cash-flow target as a determinant of its CEO's compensation because unlike earnings cash flow is "clean" and cannot be manipulated.
} 


\section{METHODOLOGY}

\section{Research Design}

Our research design concerns three important choices: the focus on abnormally large option exercises, the use of a matched pair sample design, and the selection of 1992 as the first sample year. The first research design choice is our focus on abnormally large exercises. Unlike us, prior studies investigating stock price performance after option exercises have typically used all exercises occurring in their sample period, and in particular have not distinguished between small exercises and large exercises. Thus their conflicting findings may have resulted from tests with reduced power as small exercises are more likely to be driven by liquidity or diversification needs than by private information.

Since a typical executive stock option vests within five years but expires after ten years, managers have substantial latitude in timing exercises. Given this latitude, one way for managers to increase their cash payouts from an exercise will be to first inflate earnings (and thus the stock price and the value of the option), and then exercise concurrently a number of layers of vested options from different grants. Note that a small exercise is unlikely to justify such earnings inflation; for a small exercise, the net effect of earnings inflation on the cash payout, which is increasing in the size of the exercise, is likely to be negative due to, among other things, the reductions in the value of new grants received around the exercise date. In other words, the motivation underlying small exercises is likely to be non-informational (e.g., liquidity needs), whereas that underlying large exercises is likely to be informational. Thus, focusing on large exercises should increase the percentage of information motivated exercises in our sample and thus the likelihood of documenting private-information-based exercise, if it exists. 
Our second research design choice is a matched pair sample design, where we match a firm-year with abnormally high exercise with a firm that in the exercise year (year 0 ) has normal exercises but is otherwise similar, i.e., from the same industry (on the basis of 2-digit SIC code), closest in market capitalization, belonging to the same stock-return quintile in year -1 , and is not in the test sample in the current or prior years. ${ }^{6}$ This research design controls for industry, firm size, pre-exercise stock-price performance, and time, and thus should isolate the effect of abnormally high option exercise on the performance of test firms. One reason we use firm-years, not firm-quarters, is because our source for compensation data, the S\&P EXECUCOMP database, provides stock-option-exercise data only on an annual basis. This does not allow us to precisely pinpoint when during year 0 the option exercise actually took place. Nevertheless, in our analysis we consider year 0 a pre-exercise year. This approximation holds exactly only if all exercises occur on the last day of the year. Since in reality exercises occur throughout year 0 , noise is introduced, which may weaken the power of our tests.

Finally, our sample period spans the ten-year period, 1992-2001. We chose 1992 to be our first sample year for two reasons. First, the data on EXECUCOMP are available continuously only from 1992. Second, the major regulatory change surrounding stock option exercises, which eliminated the six-month holding period restriction on stock acquired through option exercise and thus enabled insiders to sell such stock immediately, became effective in May 1991. This change is important because it changes the theoretical relation between exercise decisions and the nature of private information about a firm's prospects. Specifically, the use of private information to time exercises implies positive post-exercise returns in the old regime and

\footnotetext{
${ }^{6}$ We only look back, not forward, when requiring that a control firm not be in the test sample to avoid a look-ahead bias.
} 
negative post-exercise returns in the new regime. ${ }^{7}$ The last sample year is 2001 because this is the latest year for which data are available given that our tests require data from a post-exercise period.

\section{Variable Definitions}

Our tests concern abnormally large option exercises, stock-return performance, earnings performance, analyst-forecast accuracy, and discretionary and non-discretionary accruals. Abnormally large option exercises can, in principle, be defined using either other firms in the sample as a benchmark or with respect to the firm's own historical exercise patterns. We choose the latter because of substantial cross-sectional variation in option granting and option exercise.

Specifically, the size of option exercises is measured as the proportion of compensation from stock option exercise, averaged across the 5 most highly compensated executives. ${ }^{8}$ Abnormally large option exercises are identified by examining the ratio of this proportion with the average from the past (up to three years depending on data availability). Firms for which this ratio increases by more than 50 percent are classified as having abnormally large exercises. The choice of the cutoff point represents a tradeoff between noise and sample size; a higher cutoff point is likely to reduce noise as well as sample size.

Stock returns are measured as annual raw buy-and-hold returns created from monthly

\footnotetext{
${ }^{7}$ For a detailed discussion of this point see Carpenter and Remmers (2001).

${ }^{8}$ Alternatively, we measure the size of executive stock option exercise as either the dollar value of stock option exercise on exercise date, summed across the top 5 compensated executives or the ratio of total number of shares acquired through exercises summed across the top 5 compensated executives to the number of shares outstanding. For parsimony, we report results using the proportion of compensation from stock option exercise. However, the results are qualitatively similar if either of the other two measures is used. Also, we aggregate exercises at the firm level in three alternative ways: for the chairperson and CEO, for all board directors, and for the top 5 highest compensated executives. Our results are similar irrespective of which aggregation method is chosen. We report results using the 5 highest compensated executives because this measure is widely used in the compensation literature.
} 
returns retrieved from the CRSP Monthly Returns File, which covers NYSE, AMEX and NASDAQ. Returns are compounded starting from the beginning of the fifth month after the end of the prior fiscal year to ensure that the prior year's financial information has been released. In our tests, we focus on the annual difference in raw returns between the test firms and the control firms. These returns are hence size, industry and performance adjusted by the nature of the control sample selection process, and according to Barber and Lyon (1997, p. 370) are likely to yield well-specified test statistics. Still, we assess the sensitivity of our stock-return results to alternative risk adjustments by using Carhart's (1997) 4-factor model to estimate abnormal returns. $^{9}$

We measure earnings performance in two alternative ways: the change in net income before extraordinary items (Compustat data item \# 18) and the change in operating income (Compustat data item \# 13, commonly referred to as EBITDA). Both measures are scaled by beginning total assets.

We define a scaled analyst earnings forecast error (S_ERR) as:

$$
\mathrm{S}_{-} E R R=\frac{E P S_{a c t}-F_{-} E P S}{P}
$$

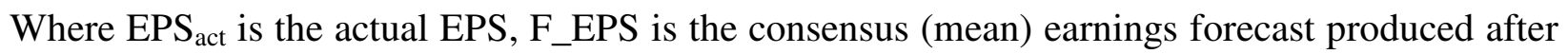
the end of the fourth month of the prior fiscal year, and $\mathrm{P}$ is the stock price at the time of the forecast. EPS act $_{1}$ F_EPS, and P are all retrieved from IBES to ensure data consistency. However, unscaled errors may be a better proxy for earnings surprises if, as recent literature suggests,

\footnotetext{
${ }^{9}$ The 4-factor model may be formally stated as follows:

$$
R_{i}-R_{f}=\alpha+\beta_{1}\left(R_{m}-R_{f}\right)+\beta_{2} S M B+\beta_{3} H M L+\beta_{4} U M D+\varepsilon
$$

where, $\mathrm{R}_{\mathrm{i}}$ minus $\mathrm{R}_{\mathrm{f}}$ is the monthly return for the ith sample firm in excess of the one-month T-bill return; $\mathrm{R}_{\mathrm{m}}$ is the value weighted monthly return on the market portfolio that consists of all NYSE, AMEX and NASDAQ firms; SMB (Small Minus Big), HML (High Minus Low), and UMD (Up Minus Down) are monthly returns on value weighted, zero investment, factor mimicking portfolios for firm-size, book-to-market equity, and one-year momentum in stock returns, respectively. For more details on this model see Carhart (1997).
} 
market participants focus on the unscaled numbers (e.g., Bartov, Givoly, and Hayn 2002). Our tests thus also consider unscaled errors, ERR, as an alternative to S_ERR.

We estimate discretionary accruals by using the cross-sectional Jones (1991) model (Bartov et al. 2000) adjusted for lagged return on assets (Kothari et al. 2003), as follows:

$$
\frac{T A_{t i j}}{A_{t-1, i j}}=\beta_{1} \frac{1}{A_{t-1, i j}}+\beta_{2} \frac{P P E_{t i j}}{A_{t-1, i j}}+\beta_{3} \frac{\Delta R E V_{t i j}}{A_{t-1, i j}}+\beta_{4} \frac{R O A t-1, i j}{A_{t}-1, i j}+\varepsilon_{t i j}
$$

Where:

$T A_{t i j}$ is total accruals in year $t$ of the $i t h$ firm in the $j t h$ industry, measured as the difference between income before extra-ordinary items and cash flow from operations in year $t$ (Collins and Hribar 2002);

$A_{t-1, i j}$ is total assets at the end of year $t-1$ of the ith firm in the $j t h$ industry;

$P P E_{t i j}$ is gross property plant and equipment at the end of year $t$ of the ith firm in the $j t h$ industry; $\triangle R E V_{t i j}$ is revenues in year $t$ less revenues in year $t-l$ of the ith firm in the $j t h$ industry; $R O A_{t-1, i j}$ is lagged return on assets; and $\beta_{1}, \beta_{2}, \beta_{3}$, and $\beta_{4}$ are parameters to be estimated.

Equation (3) is estimated by using data from all firms matched on year $t-1$ and 2-digit SIC industry groupings. The parameter estimates from this regression are then used to estimate the prediction error from Equation (3) in year $t$. This error serves as our proxy for discretionary accruals in year $t$. Non-discretionary accruals are the difference between total accruals and discretionary accruals.

\section{Sample Selection and Descriptive Statistics}

Table 1 summarizes the sample selection procedure. In the period 1992-2001, there are 17,970 observations with valid compensation data on the Standard \& Poor's EXECUCOMP 
database corresponding to 2,507 distinct firms. We drop 6,413 firm-years (343 firms) because lagged exercise data required in order to determine whether the current exercise is abnormally large are unavailable, reducing the sample size to 11,557 observations (2,164 firms). Next, 7,829 firm-years (387 firms) whose exercise size is below our cutoff are deleted as well as 1,727 observations (0 firms) representing same firm exercises that are less than three years apart (retaining the earlier occurrences), reducing the sample size to 2,001 firm-years corresponding to 1,777 distinct firms with abnormally large executive option exercise that are at least three years apart and have required data on EXECUCOMP. We then delete 427 firm-years (343 firms) due to inability to find matches. Finally, we eliminate 252 firm-years (216 firms) due to missing return data on the Center for Research in Security Prices (CRSP) database. Our final sample thus consists of 1,322 firm-years corresponding to 1,218 distinct firms. ${ }^{10}$

Table 2 presents the distribution of the sample firms across industry (Panel A) and time (Panel B). As the results in Panel A indicate, our sample spans more than 30 different 2-digit SIC codes, and no industry accounts for more than 10 percent of the sample; there is little evidence of industry clustering in the sample. Among the industries that are well represented are Business Services (SIC 73) with 132 observations (10.0 percent), Electronics (SIC 36) with 121 observations (9.2 percent), and Chemicals (SIC 28) with 111 observations (8.4 percent). Panel B presents the distribution of the abnormally high option exercises over the sample period. There is an increasing trend over time for the sample subperiod, 1993 - 1997, and a decreasing trend thereafter. The increasing trend may be attributed to the increasing coverage of EXECUCOMP over the decade, the increasing popularity of executive stock options, and the bull stock market

\footnotetext{
${ }^{10}$ Tests involving annual earnings changes, discretionary accruals, or analyst earnings forecasts have smaller number of observations due to the additional data requirements of these tests.
} 
of the 1990s. The decreasing trend may be due to the bear market of the early 2000s and to our requirement that same firm's large exercises will be at least three years apart.

Table 3 presents descriptive statistics. In Panel A, the test sample is compared to the control sample in the event year. Both test firms and control firms have similar mean and median sales and assets. The mean sales and assets are approximately $\$ 3$ billion and $\$ 7.4$ billion, respectively, for the test sample, and $\$ 2.8$ billion and $\$ 6.2$ billion, respectively, for the control sample. This indicates that our sample-selection procedure is successful in matching test and control firms on firm size. However, by design the two samples display economically and statistically significant differences in stock option exercises. For the test sample, the top 5 executives combined earned on the average $\$ 5.59$ million from stock option exercise (29.1 percent of total compensation) as opposed to only $\$ 0.91$ million (7.4 percent of total compensation) for the control-sample firms. Furthermore, the evidence in Panel B, comparing test firms' exercises in event and non-event years, indicates that the mean exercises of $\$ 5.59$ million (29.1 percent of total compensation) in the event year is nearly 500 percent higher than the mean exercise in non-event years ( $\$ 1.15$ million; 9.1 percent of total compensation). Thus, both the cross-sectional comparison and the time-series comparison indicate our sample selection procedure has successfully identified firm-years where stock option exercises are abnormally high.

Do top executives sell or retain shares acquired through option exercise? To gain insights into this question we compare the amount of stock option exercise with the amount of stock sold in event and nonevent years for a subsample of firms with available stock sales data on Thomson Financial's Insider Trading database. This database has a file called Table 1 which provides information on insider stock sales and purchases. In this file, we look for all sales for executives 
marked as either CEO or Chairman and add these sales to get the entire sale for the fiscal year. ${ }^{11}$ Panel $\mathrm{C}$ of Table 3 displays the results which indicate that in all years the amount of stock sold exceeds the amount of stock option exercise. Furthermore, stock sales are much higher in years of high exercise than in other years, providing prima-facie evidence that executives sell shares acquired through option exercise rather than retain them.

\section{TESTS AND RESULTS}

\section{Stock Returns around Stock-Option Exercises}

Prior research provides conflicting evidence on the ability of top-level executives to time stock-option exercises. Our first objective is to reexamine whether such timing ability exists by developing potentially more powerful tests. As discussed above, the increased power follows from our research-design choice to focus on abnormally large exercises. We hypothesize that top-level executives use private information to time stock-option exercises so as to increase the cash payout from these exercises.

If an equity stakeholder privately receives bad news about the future prospects of his company, he may wish to reduce his position. Given this, and given that executive stock options represent a nontransferable long position in the company stock, negative private information about the company's future performance may trigger option exercising and selling of the acquired stock. Indeed, optimal exercise decisions vary with the strike price, interest rate, dividend rate, and the tax rate. Still, for a given set of values for these parameters, the gloomier the future stock price forecast is, the more likely the optimal exercise decision to shift from holding the option to exercising it and selling the acquired stock. Given this, and given that an

\footnotetext{
${ }^{11}$ Unlike the other tests, for this analysis we aggregate exercises at the CEO/Chairman level. This follows because it is impossible to accurately match the 5 most highly compensated employees between EXECUCOMP and Thomson Financial's Insider Trading database, which provides insider trading data.
} 
executive's private information typically represents knowledge about firm-specific events, an empirical prediction of our hypothesis is that in the post-exercise period negative abnormal stock returns will be observed. ${ }^{12}$

Our prediction entails the assumptions that shares acquired through option exercise are sold immediately rather than retained, and that the timing of option exercises is picked by management rather than dictated exogenously by, e.g., option expiration. These two assumptions, which follow from data limitations, should not be overemphasized given our findings (Panel C of Table 3) and those in prior research (Ofek and Yermack 2000; Huddart and Lang 2003, footnote 1) indicating that during our sample period a typical manager sells most shares acquired through option exercise and that most exercises occur long before expiration (see, e.g., Huddart and Lang 1996). ${ }^{13}$

Table 4 displays the results from the size-industry-performance-adjusted stock-return tests for the full sample (Panels A, and Figure 1), and for subsamples grouped by firm size (Panel B) and time period (Panel C). It also displays full sample return results based on the 4factor model (Panel D), and return results for all exercises as in Carpenter and Remmers (Panel E). ${ }^{14}$ The stock returns reported for the test firms and control firms are annual raw returns (the only exception is Panel D, which reports monthly returns adjusted for risk using the 4-factor model). The return difference between the test and control firms is size-industry-performanceadjusted returns (abnormal returns) because test firms and control firms are matched on industry, size, and prior year stock-price performance.

\footnotetext{
${ }^{12}$ For a formal analysis establishing that the use of inside information to time exercises implies negative postexercise returns see Carpenter and Remmers (2001).

${ }^{13}$ In addition, it can be shown theoretically that employee option holders generally should not hold the stock after exercise for tax reasons (see, e.g., Scholes et al. 2004).

${ }^{14}$ In panels A-D, the exercise year (year 0) spans the nine-year period, 1993-2001. Year 1992 is omitted because data limitations dictate that the first year for which large exercises can be identified is 1993.
} 
The results in Panel A indicate that prior to exercises, the stock prices of test firms rise substantially on average. The means of raw returns for the test sample in years $-3,-2,-1$, and 0 (year 0 is the exercise year), are respectively, 20.4 percent, 31.6 percent, 45.3 percent, and 35.4 percent. The stock prices of control firms also rise in the pre-exercise period, 20.4 percent in year $-3,21.6$ percent in year $-2,45.8$ percent in year -1 , and 26.2 percent in year 0 . The return difference between the test sample and the control sample is significant in years -2 (10.0 percent) and 0 (9.2 percent), and close to zero in years -3 and -1 (year -1 result is by the construction of the sample). It is not surprising that executives exercise nontransferable options after a stock price run up that causes the risk-reward balance associated with holding an option to shift. This evidence may thus be consistent with a rational exercise policy which entails exercising stock options when the price of the underlying stock is sufficiently high; the evidence is not sufficient to allow inference on the use of private information to time exercises. Such inference must be based on tests of stock return performance in a post-exercise period.

Turning to the test results for our hypothesis, displayed in the two rightmost columns of Panel A, the return difference between the test and control samples in the post-exercise period is negative and highly significant. ${ }^{15}$ Specifically, the mean abnormal return (i.e., size-industryperformance-adjusted return) for year +1 is -11.2 percent and is highly significant. In year +2 the mean abnormal return is much smaller, only -2.6 percent, and is statistically insignificant. These negative abnormal returns in the post-exercise period, -7.2 percent on average (weighted by the number of observations in each year) for the two years, +1 and +2 , contrast with the 4.4 percent positive abnormal returns in the two years leading up to the exercise year, years -1 and 0 (the return difference between the two subperiods, -11.6 percent, is highly significant). Overall, these results are consistent with the hypothesis that top-level executives use private information

\footnotetext{
${ }^{15}$ Although all our hypotheses are directional, for conservatism we report significance levels using two-tailed tests.
} 
to time stock-option exercises so as to increase the cash payout from these exercises.

Carpenter and Remmers (2001) find a differential timing effect of exercises based on firm size. Specifically, while for their post-1991 sample period they generally fail to document significant negative returns following top-management exercises, they do find such result in a tiny subsample of small firms. Do exercises of executives of small firms drive our results? While both Carpenter and Remmers' sample and our sample consist predominantly of large firms, we assess a possible size effect on our findings by replicating the tests in Panel A after partitioning the sample into three subsamples of small, medium, and large firms on the basis of their NYSE/AMEX/NASDAQ Capitalization Deciles in CRSP. Small firms are those in deciles 1-6; medium firms in deciles 7-8; large firms in deciles 9-10. Panel B of Table 4 displays the results from this analysis. The stock-return pattern observed for the full sample also holds up for each of the three subsamples, indicating that the findings in Panel A are robust to firm size and in particular are not driven by exercises of executives in small firms.

Another potential concern is that the results in Panel A might have been confounded by unusual market performance in a short subperiod, e.g. the stock price bubble in the 1990s. To address this, we replicate the tests in Panel A after partitioning our sample into three subperiods: 1993-1996, the pre-boom period, 1997-1999, the boom period, and 2000-2001, the meltdown period. The results, displayed in Panel C, indicate that for all three subperiods the stock-return trends are similar. The abnormal returns are generally positive in the pre-exercise period, turn significantly negative in year +1 , and are insignificant in year +2 . This robustness across sample periods increases confidence that our findings are not period specific.

Panel D displays the results from using Carhart's (1997) 4-factor model to generate abnormal returns. Specifically, along the lines of Fama and MacBeth (1973) we estimate the 
cross-sectional relation (Equation 1 above) monthly from the beginning of year -3 to the end of year +2 separately for the test and control samples. This yields 72 monthly cross-sectional regressions for each sample (six years time twelve regressions per year). The intercept $(\alpha)$ of each of these 72 monthly regressions is the estimate of the monthly abnormal stock return. We then average the intercepts by year (and sample), and use the t-statistics associated with these averages to test our hypothesis that in the post-exercise period the abnormal stock returns for “Test minus Control” are negative.

Similar to the abnormal-stock-return pattern reported in Panel A, the generally positive abnormal returns for the Test minus Control sample in the period leading up to the exercise turn significantly negative after the exercise. In addition, the results in Panel A and Panel D are quite similar in terms of magnitudes. For example, the Test minus Control's average annual abnormal return over the years +1 and +2 is -7.2 percent in Panel A and -6.5 percent in Panel D. ${ }^{16}$ Thus our return results are robust to alternative risk adjustments.

Finally, we examine the effect on the findings of our design choice to focus on abnormally large exercises. Recall that we made this choice in an effort to increase power in light of Carpenter and Remmers' (2001) failure to find evidence that the timing of executive option exercises predict stock return future performance. We thus repeat the tests in Panel A using Carpenter and Remmers' sample period (i.e., 1992-1995), and sample selection criteria (i.e., including all option exercises available from EXECUCOMP). The results, displayed in Panel E, indicate that using their sample selection criteria and period leads to results similar to theirs. Specifically, while the pre-exercise run-up in stock prices is observed, the post-exercise stock price reversal is not. This illustrates why our results differ from those in Carpenter and

\footnotetext{
${ }^{16}$ The monthly return in Panel D is annualized as follows: $(1-.0056)^{12}-1=-0.065$
} 
Remmers, and more importantly highlights the critical role that the focus on abnormally large option exercises plays for our findings.

\section{Earnings Performance and Analyst Earnings Forecast Errors around Stock-Option Exercises}

Our next two hypotheses concern the nature of private information underlying the ability of top-level executives to time option exercise. We first hypothesize that the pattern of exercises is consistent with executive option holders (partially) basing their exercise decisions on private information about future earnings and, second, that top-level executives inflate accruals and thus earnings prior to option exercise so as to increase the cash payout from exercises.

There is no shortage of evidence in both the financial press and the academic literature indicating the importance of earnings news in explaining stock-price changes. For example, Ball and Brown (1968), as well as numerous follow-up studies, have documented a positive relation between earnings surprises and stock price performance, Biddle, Seow, and Siegel (1995) provide evidence consistent with investors relying on earnings more than any other summary measure of performance (e.g., dividends, or EBITDA, a variant of earnings), and Graham, Harvey, and Rajgopal (2003) report that corporate executives perceive earnings as the key variable used by investors and financial analysts. This implies that private information of disappointing future earnings might motivate early stock-option exercises and sales of shares acquired through exercises. To test this hypothesis, we examine annual earnings changes and analyst earnings forecast errors around the exercise year.

With respect to earnings changes, our hypothesis implies negative annual earnings changes in the post-exercise period. As before, the empirical tests center on the difference between test and control firms because an executive's private information typically represents 
knowledge about firm-specific events. Table 5 and Figure 2 report the results for these earningschanges tests, where earnings is defined either as net income before extraordinary items or as operating income, and both variables are scaled by lagged total assets.

Prior to exercises, both test firms and control firms exhibit earnings growth. For example, the results in Panel A indicate that the annual change in net income before extraordinary items increases from 1.4 percent in year -3 to 2.0 percent in year 0 for the test firms and from 0.7 percent to 1.3 percent per year for the control firms. The differences in the change in net income before extraordinary items between test and control firms are all positive, albeit (marginally) significant only in years -3 and 0 . Thus, while both types of firms exhibit improved earnings performance in the pre-exercise period, this pattern is more pronounced for the test firms. However, a pattern of improved earnings prior to exercises is not sufficient to allow inferences on the use of private information to time exercises, as it is also consistent with an alternative explanation that this pattern is related to a shift in the risk-reward balance associated with holding an option, which leads to exercise. Inferences on the use of private information must entail testing earnings performance in a post-exercise period.

In contrast to the test firms' observed pattern of improving earnings performance in the pre-exercise period, the results for the post-exercise period highlight deteriorating earning performance. For example, the differences in the annual change in net income before extraordinary items are (marginally) significantly negative in year $+1,-0.6$ percent. Comparing the annual earnings performance in the pre- and post-exercise periods indicates a more pronounced deteriorating performance. For example, the difference in the change in annual income before extraordinary items between the test and control samples is, on the average, 0.4 percent in the pre-exercise period (years $-1,0$ ) and -0.4 percent in the post-exercise period (years 
$+1,+2)$, and the difference between these two averages $(-0.8$ percent) is highly significant. These findings are consistent with the negative return results reported in Table 4, and are thus consistent with our hypothesis that top-level managers based the timing of exercises (partially) on private information concerning future earnings performance of their firms.

According to Ball and Brown (1968, Table 5), approximately 85 percent of information in annual earnings leaks to the market prior to their formal release. Thus, if managers use private earnings information to time exercises, some of this information will be released around earnings announcements in the post-exercise period while most of it will be released prior to these announcements through more timely means. In the context of our hypothesis, this implies that in the post-exercise period annual unexpected earnings for our test firms will be negative. As is standard in the literature, we use analyst earnings forecast errors as a proxy for unexpected earnings.

Table 6 and Figure 3 report the results from these tests. Two salient points emerge from reviewing the Table and Figure. First, numerous studies have documented that analyst earnings forecasts made early in the fiscal year are optimistically biased. ${ }^{17}$ Consistent with findings in this literature, the results in Table 6 indicate that the means of both S_ERR (the scaled forecast error) and ERR (the unscaled forecast error) are negative for all years for both test and control firms. While this finding increases confidence that there is nothing unusual about our test and control samples, it makes analyst forecast errors hard to interpret. To address this problem, our tests focus on the difference in analyst forecast errors between the test firms and the control firms. Taking such difference should purge the bias because there is little reason to believe that

\footnotetext{
${ }^{17}$ Market observers and regulators have also taken notice of this optimistic bias. For example, asked about securities firms' research, the Federal Reserve Chairman Alan Greenspan said, "there has clearly been an optimistic bias in the reports." He then goes on to explain that this bias follows partly because "people who are forecasters and tend to be gloomy don't get hired by securities-analysts' firms." (The Wall Street Journal 2003b).
} 
the optimistic bias in analyst earnings forecasts relates to the timing of exercises.

Second, in the pre-exercise period, year -3 to year 0 , the forecast errors (scaled and unscaled) for both test and control sample are decreasing (in absolute values), and the error for Test minus Control is positive and marginally significant in year 0 , and insignificant in other years. In contrast, in year +1 the error for the test sample increases dramatically (more than doubles in absolute value). Furthermore, as predicted, the error for Test minus Control turns negative, -0.2 percent and marginally significant for the scaled error (S_ERR), and -0.03 and highly significant for the unscaled error (ERR).

Overall, the patterns in tables 5 and 6 are similar; they are consistent with the hypothesis that managers use private information about disappointing future earnings to time exercises, as even sophisticated market participants (financial analysts) are unable to decipher this information. A natural question that arises from this evidence is whether the private earnings information is about discretionary earnings or nondiscretionary earnings. This question is investigated in the next section.

\section{Accruals Behavior around Stock-Option Exercises}

There is ample evidence in extant research indicating opportunistic managerial behavior under a variety of circumstances. One strand of this literature shows that corporate executives manage earnings to increase their earnings-based bonuses (see, e.g., Healy 1985), by exploiting the managerial discretion inherent in the computation of earnings. Following the findings in this literature, we hypothesize that top-level executives inflate earnings prior to abnormally large option exercises so as to increase the cash payout from such exercises. Indeed, underlying this hypothesis is the premise that investors are unable to decipher fully earnings management, which 
is plausible due to the information asymmetry between a firm's insiders and outsiders. Furthermore, anecdotal evidence is consistent with our hypothesis. For example, the Securities and Exchange Commission (SEC) charged that HealthSouth's former chairman and CEO "has personally profited from the scheme to artificially inflate earnings" by selling at least 7.8 million shares of his company since 1999. (See, The Wall Street Journal 2003c).

To test this hypothesis, we examine discretionary accruals, our proxy for earnings manipulation, around option exercise. Evidence of positive discretionary accruals in the period leading up to the exercise will be consistent with our hypothesis. We focus on discretionary accruals because prior studies have used discretionary accruals as a proxy for earnings management (e.g., Jones 1991; Balsam et al. 2002) as well as documented that discretionary accruals and stock prices are positively correlated (e.g., Subramanyam 1996).

Table 7 and Figure 4-A and Figure 4-B display the results from these tests. As before, to purge possible industry-wide effects, we perform the statistical tests on the difference between test and control samples. The results in Panel A indicate that in the pre-exercise years the difference in discretionary accruals is generally insignificant (the only exception is year -3 where it is significantly negative) as is the difference in non-discretionary accruals. Consistent with our prediction, however, in year 0 the difference in discretionary accruals between test and control samples increases dramatically, to 0.9 percent, and turns significant. These findings are consistent with our hypothesis that, prior to exercise, top-level managers inflate discretionary accruals and thus earnings to increase the cash payout from exercise. In addition, comparing annual discretionary accruals in the pre-exercise and post-exercise periods shows that discretionary accruals of the test firms, but not of the control firms, are significantly higher in the former. These findings provide further evidence consistent with our hypothesis. 
Finally, unlike discretionary-accruals, the differences in non-discretionary accruals between test and control samples are relatively stable across the six years, and in particular are all statistically insignificant. These results make it less likely that changes in real economic activity underlie the earnings patterns observed around large top-management exercises; they are thus further consistent with our hypothesis that prior to exercise top-level managers inflate earnings to increase the cash payout from exercise.

Are the statistically significant abnormal discretionary accruals observed prior to exercise economically meaningful? To answer this question we examine the impact of discretionary accruals on sample firms' earnings performance around the exercise year. Panel B of Table 7 reports the results from these tests. As before (Table 5 above), in the period leading up to the exercise year the difference between test and control samples in terms of annual income changes are significantly positive. ${ }^{18}$ However, once discretionary accruals are excluded from the calculation of the income change, this positive earnings performance subsides. Specifically, including the effect of discretionary accruals, income is up significantly in year 0 (1.06 percent), whereas excluding discretionary accruals the income change is insignificant in year $0(0.20$ percent). In addition, while the positive earnings performance in year 0 turns negative $(-0.73$ percent) in year +1 , excluding discretionary accruals there is little change in the earnings performance between years 0 and +1 . Overall, these results indicate that the effect of discretionary accruals on the earnings performance of the test firms in the pre-exercise period is statistically significant as well as economically meaningful.

\footnotetext{
${ }^{18}$ The reason for the decline in number of observation between Table 5 (1,045 observations) and Panel B of Table 7 (790) is the additional data requirement that discretionary accruals be available.
} 


\section{Sensitivity Tests}

In this section we consider the effect of stock option grants on our findings. One consequence of inflating earnings, and thus the stock price prior to exercise, is that the exercise price of new option grants occurring in the same period is also inflated because nearly all stock options are granted with a fixed exercise price equal to the stock price on the grant date. Because the value of a stock option and its exercise price are negatively related, it is arguable that some or perhaps even all of the benefits from temporarily inflating the stock price associated with exercise may be offset by the loss in the value of new grants. Note, however, that this loss in value is unlikely to be significant for a number of reasons including the time value of money, the common practice among U.S. corporations of repricing underwater executive stock options, and in particular our focus on large exercises. Still, we perform two types of tests to assess the effect of new grants on our results.

In the first type we compare option exercises and option grants between test and control samples for the six year period around the exercise year. Panel A of Table 8 presents the results of this comparison. ${ }^{19}$ There are three points to note. First, the control sample's means of option exercises in the pre-exercise period, $\$ 1.75, \$ 1.87$, and $\$ 1.88$ in years $-3,-2$, and -1 , respectively, are nearly twice as large as those of the test sample, $\$ 1.10$ in year $-3, \$ 0.82$ in year -2 , and $\$ 1.05$ in year -1 (\$ figures are in million). This finding, which indicates a low rate of exercise of test firms relative to the control firms in the pre-exercise period, is consistent with the intuition underlying our hypotheses that large exercises represent a decision by executives of test firms to simultaneously exercise a number of layers of vested options from different grants.

\footnotetext{
${ }^{19}$ To allow an over time comparison, in Panel A of Table 8 we impose an additional data restriction that exercise and grant data be available for the four year period, $-2,+1$. This results in a loss of approximately 30 percent of the sample. Still, a comparison of the exercise statistics for year 0 displayed in Panel A of Table 3 (full sample) and Panel A of Table 8 (reduced sample) demonstrates that the additional restriction has only a minor effect on the results.
} 
Second, grants for the test and control samples increase monotonically over time and grants of test firms exceed those of the control firms. Still the differences in grants between test and control samples in years -3 to -1 are rather stable and cannot explain the jump in exercises for the test firms in year 0 . In other words, the substantial increase in annual exercises, from an average of approximately $\$ 1$ million per year in the pre-exercise period to $\$ 5.40$ million in year 0, does not follow because of unusually large grants in the preceding period. Finally, the results displayed in the three rightmost columns of Panel A indicate that in years -3 to -1 the proportion of firms with grants exceeding exercises for the test firms is significantly greater than the one for the control firms. Conversely, in the exercise year (year 0) this proportion drops substantially for the test sample and increases for the control firms; the proportion of firms with grants exceeding exercises for the control sample (74.9 percent) significantly exceeds the one for the test sample (51.2 percent). Overall, these findings are consistent with the view that large exercises represent a strategic decision by executives to cash out an abnormally large number of options at a specific point in time.

The second type of tests concern a more direct examination of the effect of new grants on our findings by replicating the earnings performance tests, stock-return tests, and discretionary accruals tests after partitioning the sample into two subsamples: one with low grant observations relative to exercises (Panel B) and the other with high grant observations (Panel C). As may be expected, the results indicate that new grants have little effect on our findings.

\section{CONCLUSION}

Economic theory and corporate executives argue that executive stock option awards are an efficient means to align the interest of management and shareholders and thereby enhance 
shareholder value. Researchers, however, have identified instances where options have induced managers to act opportunistically rather than in the interests of shareholders. For instance, CEOs manipulate the option grant date (Yermack 1997) or disclosures around it (Aboody and Kasznick 2000) to increase the value of their stock-option compensation. Yet, the results pertaining to the ability of top-level executives to time the exercises of their stock options are mixed. Carpenter and Remmers (2001) find little evidence of such timing in the 1990s, while Huddart and Lang (2003) find that the timing of option exercises can be used to predict future stock returns.

This study, which uses a sample of stock option exercises by top manages of more than 1,200 public corporations in the period 1992-2001, has two primary objectives. First, we develop potentially more powerful tests that help determine whether such timing ability exits. Unlike prior research analyzing all exercises, we focus on abnormally large exercises where the incentives for private-information-based exercise are greater and thus easier to detect, if they exist. Consistent with Huddart and Lang (2003), we find evidence of reversals in stock returns around the year in which abnormally large exercises by top-level executives occur. Specifically, abnormally positive stock price changes in the pre-exercise period turn abnormally negative after the exercise. Furthermore, when we repeat these tests using Carpenter and Remmers' (2001) sample period (i.e. 1992-1995) and sample selection criteria (i.e., including all exercises available from EXECUCOMP), we, like them, find no evidence of stock price reversals in the post-exercise period. These findings are consistent with the hypothesis that top-level executives use private information to time abnormally large exercises, where the benefits from such timing are maximized. ${ }^{20}$

\footnotetext{
${ }^{20}$ Note that after the dust settles (i.e., after accruals totally reverse), earnings will return to their normal levels and the stock price is likely to be the same as if manipulation has not occurred (less the cost of the settlement of the exercise at inflated price). This implies that executive option holdings after the exercise are not that relevant. In other words, the temporary stock price inflation allows the manager to increase his cash payout. In the absence of manipulations,
} 
Second, we investigate the nature of the private information used by corporate executives to time stock option exercises. We analyze the earnings performance of firms with abnormally large exercises to see if the observed trend in stock returns reflects private information about future earnings. We find that in the pre-exercise period, annual earnings changes are abnormally positive, while in the post-exercise period earnings changes are abnormally negative. Hence managers' ability to time option exercises is related to the trend in earnings performance. Furthermore, analyzing errors in analyst earnings forecasts indicates that financial analysts do not anticipate either the over-performance in the pre-exercise period or the under-performance in the post-exercise period. This is further consistent with the interpretation that the observed earnings patterns represent private information held by top-level managers, as even sophisticated market participants appear unable to decipher this information.

We next hypothesize that managers exploit their considerable discretion in the computation of earnings to inflate earnings in the pre-exercise period to increase their payout from exercises. Consistent with this hypothesis, we find that in the pre-exercise period discretionary accruals, but not non-discretionary accruals, are abnormally high, and that these abnormally high discretionary accruals underlie the abnormally positive earnings performance observed in the pre-exercise period. Moreover, in the post-exercise period, evidence indicates reversal in discretionary accruals but not in non-discretionary accruals. This evidence is consistent with the hypothesis that management inflates earnings prior to abnormally large exercises.

Our study makes the following two contributions. First, we present evidence on the nature of the private information used by executives to time exercises, thereby suggesting a link

the manger would have cashed out less money from the exercise but his remaining holdings would have had the same value. The results in Table 4 above seem consistent with this story; the 9.2 percent mean abnormal return in year 0 is followed by -11.2 percent return in year +1 . 
between option exercise decisions and private information. Specifically, our findings are consistent with private information being that the current strong earnings performance is an artifact of earnings management, timed to coincide with large exercises of options, and hence will not persist. In other words, managers inflate earnings in a pre-exercise period in an effort to increase cash payout from the exercises. This comes at the expense of future earnings when the accruals reverse, but apparently managers still benefit from this activity as they have already cashed out a large portion of their option holdings at inflated prices.

Second, our findings highlight the importance of looking at abnormally large option exercises. Prior studies investigating exercise decisions by top executives using all exercises reported conflicting evidence on timing. While Carpenter and Remmers (2001) conclude that there is little evidence to support that managers time option exercises in the 1990s, Huddart and Lang (2003) arrive at an opposite conclusion.

It is important to consider some caveats regarding our results. The evidence we present is consistent with earnings manipulation around large option exercises, which can be seen in the pattern of abnormally high discretionary accruals in the pre-exercise period that turn abnormally low in the post-exercise period. One potential concern may be that discretionary accruals are bad proxies for earnings management. We attempt to alleviate this concern by using a state of the art methodology to estimate discretionary accruals and by benchmarking the discretionary accruals of our test firms against those of control firms. Still, our interpretation of the results holds only if the discretionary accruals model we use is appropriate and the control sample is suitable.

Finally, the results of this paper may present an interesting conundrum for boards of directors interested in devising effective executive compensation schemes. In theory, executive stock option awards should reduce agency costs and better align the interests of shareholders and 
management. However, in practice managers appear to inflate earnings, and consequently increase their cash payout from stock option exercises for reasons unrelated to efforts they exert or to their firm's actual economic performance, thereby potentially reducing the effectiveness of these awards. 


\section{REFERENCES}

Aboody, D., and R. Kasznick. 2000. CEO stock option awards and the timing of corporate voluntary disclosures. Journal of Accounting and Economics 29 (3): 73-100.

Ball, R., and P. Brown. 1968. An Empirical Evaluation of Accounting Income Numbers. Journal of Accounting Research 6 (Autumn): 159 - 178.

Balsam, S. 1998. Discretionary accounting choices and CEO compensation. Contemporary Accounting Research 15 (3): 229-252.

Balsam, S., 2002. An Introduction to Executive Compensation. San Diego, CA: Academic Press.

Balsam, S., E. Bartov, and C. Marquardt. 2002. Accruals management, investor sophistication, and equity valuation: evidence from 10-Q filings, Journal of Accounting Research 40 (4): 987-1012.

Balsam, S., and S. Miharjo. 2003. The Effect of Stock Options on Executive Turnover. Working paper, Temple University.

Balsam, S., H. A. Mozes, and H. A. Newman. 2003. Managing pro forma stock option expense under SFAS No. 123. Accounting Horizons 17 (1): 31-45.

Barber, B. M., and J. D. Lyon. 1997. Detecting long-run abnormal stock returns: The empirical power and specification of test statistics. Journal of Financial Economics 43 (3): 341-372.

Bartov, E., D. Givoly, and C. Hayn. 2002. The rewards for meeting-or-beating earnings expectations. Journal of Accounting and Economics 33 (2): 173-204.

Bartov, E., F. A. Gul, and J. S. L. Tsui. 2000. Discretionary accruals models and audit qualifications. Journal of Accounting and Economics 30 (3): 421-452.

Beneish, M. D. 1999. Incentives and penalties related to earnings overstatements that violate GAAP. The Accounting Review 74 (4): 425-457.

Beneish, M. D., and M. E. Vargus. 2002. Insider Trading, Earnings Quality, and Accrual Mispricing. The Accounting Review 77 (4): 755-791.

Beneish, M. D., E. Press, and M. E. Vargus. 2003. Overlooked incentives: Insider trading opportunities as a motivation for earnings management. Working paper, Indiana University.

Biddle, G., G. Seow, and A. Siegel. 1995. Relative versus incremental information. Contemporary Accounting Research 12 (1): 1-23. 
Carhart, M. M. 1997. On persistence in mutual fund performance. The Journal of Finance 52 (1): $57-82$.

Carpenter, J. N., and B. Remmers. 2001. Executive stock options and insider information. Journal of Business 74 (4): 513-534.

Cheng, Q., and T. Warfield. 2003. Stock-based compensation, earnings management to meet analysts' forecasts, and the informativeness of earnings. Working paper, University of Wisconsin.

Collins, D., and P. Hribar. 2002. Errors in estimating accruals: Implications for empirical research. Journal of Accounting Research 40 (1): 105-134.

Core, J. E., and W. R. Guay. 2001. Stock option plans for non-executive employees. Journal of Financial Economics 61 (2): 253-287.

Core, J. E., and W. R. Guay. 1999. The use of equity grants to manage optimal equity incentive levels. Journal of Accounting and Economics 28 (2): 151-184.

Fama, E. F., and J. MacBeth. 1973. Risk, return and equilibrium: Empirical tests. Journal of Political Economy 81 (3): 607-636.

Graham, J., C. Harvey, and S. Rajgopal. 2003. Financial reporting policies: evidence from the field. Duke University and University of Washington working paper.

Hanlon, M., T. Shevlin, and S. Rajgopal. 2003. Are executive stock options associated with future earnings? Journal of Accounting and Economics 36 (1-3): 3-44.

Healy, P. 1985. The effect of bonus schemes on accounting decisions. Journal of Accounting and Economics 7 (1-3): 85-107.

Henry, T. F. 2003. Earnings management and stock options. Working paper, Seton Hall University.

Huddart, S., and M. Lang. 2003. Information distribution within firms: Evidence from stock option exercises. Journal of Accounting and Economics 34 (1-3): 3-41.

Huddart, S., and M. Lang. 1996. Employee stock option exercises: An empirical analysis. Journal of Accounting and Economics 21 (1): 5-43.

Jaffe, J. F. 1974. Special information and insider trading. Journal of Business 47 (3): 410-428.

Jensen, M. C., and W. H. Meckling. 1976. Theory of the firm: Managerial behavior, agency costs, and ownership structure. Journal of Financial Economics 3 (4): 306-360. 
Jones, J. J. 1991. Earnings management during import relief investigations. Journal of Accounting Research 29 (2): 193-228.

Ke, B., S. Huddart, and K. Petroni. 2003. What insiders know about future earnings and how they use it: Evidence from insider trades. Journal of Accounting and Economics 35 (3): $315-346$

Kothari, S. P., A. J. Leone, and C. E. Wasley. 2003. Performance matched discretionary accrual measures. Working paper, MIT.

Lakonishok, J., and I. Lee. 2001. Are insiders' trades informative? Review of Financial Studies 14 (1): 79-112.

Ofek, E., and D. Yermack. 2000. Taking stock: Equity-based compensation and the evolution of managerial ownership. The Journal of Finance 55 (3): 1367-1384.

Rajgopal, S., and T. Shevlin. 2002. Empirical evidence on the relation between stock option compensation and risk taking. Journal of Accounting and Economics 33 (2): 145-171.

Scholes, M., M. A. Wolfson, M. M. Erickson, E. L. Maydew, and T. J. Shevlin. 2004. Taxes and Business Strategy: A Planning Approach. Upper Saddle River, NJ: Prentice Hall.

Seyhun, N. 1998. Investment Intelligence: From Insider Trading. MIT Press, Cambridge, Mass.

Subramanyam, K. R. 1996. The pricing of discretionary accruals. Journal of Accounting and Economics 22 (1-3): 249-281.

The Wall Street Journal, 2003a, Executive options take luster off Casino's shares, May 1, C3.

The Wall Street Journal, 2003b, Fed chief reiterates call for companies to expense options, May 9, C3.

The Wall Street Journal, 2003c, HealthSouth faked profits, SEC charges, May 20, C1.

The Wall Street Journal, 2003d, Sing of times: GE chief Immelt to get stock - not options, September 18, B1.

Yermack, D. 1995. Do corporations award CEO stock options effectively? Journal of Financial Economics 39 (2\&3): 237-269.

Yermack, D. 1997. Good timing: CEO stock option awards and company news announcements. The Journal of Finance 52 (2), 449-476. 
FIGURE 1

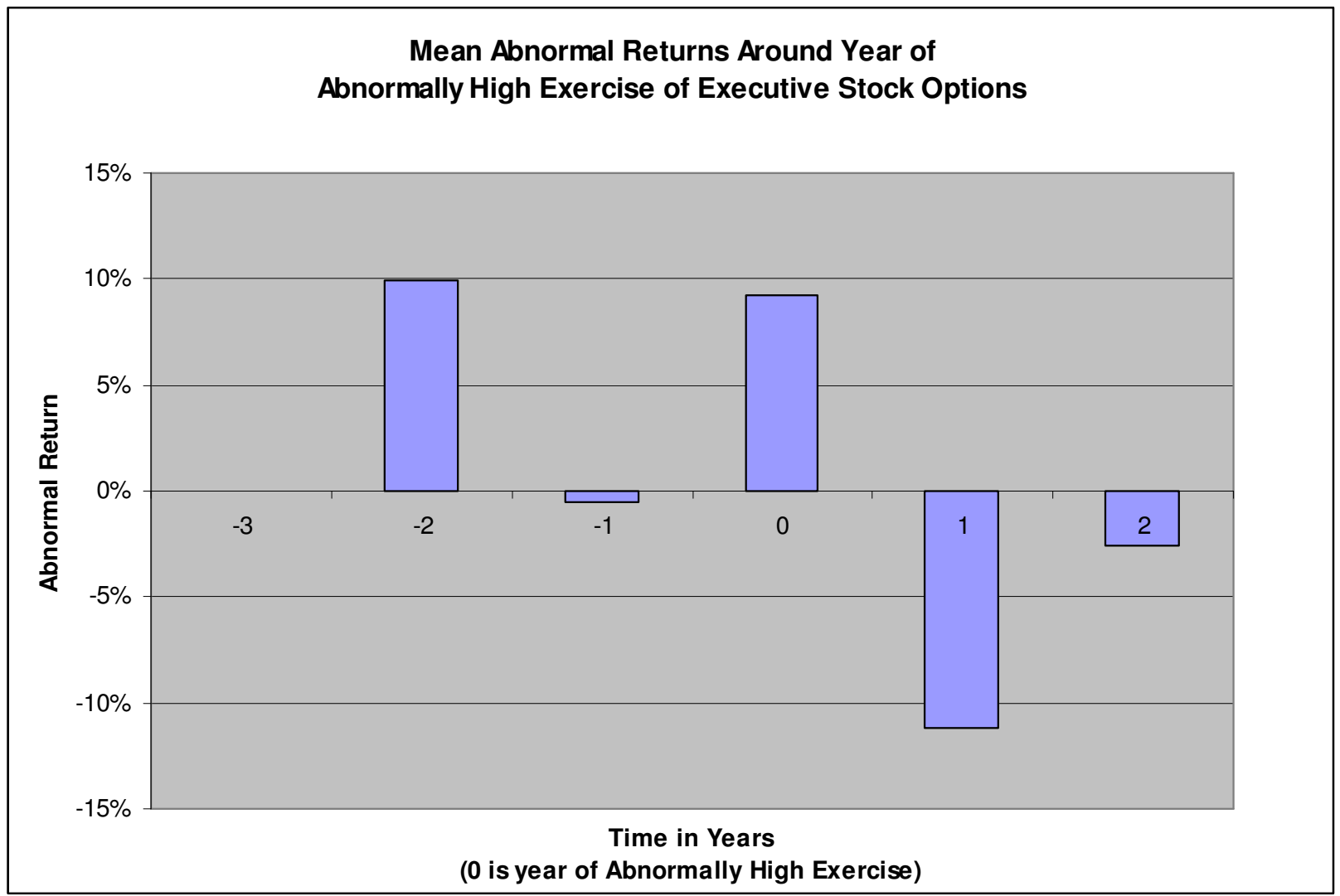

The size of option exercises is measured as the proportion of compensation from stock option exercise, averaged across the top 5 highest compensated executives. Abnormally large exercises are identified by examining the ratio of this proportion with the average from the past (up to three years). Firms for which there was a greater than 50\% increase in this ratio are classified as having abnormally large exercises. These firms are matched at the exercise year (year 0) to the closest firm in size (measured by market capitalization) in the same industry (2-digit SIC code), belonging to the same return quintile in year -1 , that did not have an abnormally large exercise. Returns are buyand-hold annual raw returns around abnormally large option exercise year (year 0). Abnormal Returns are the difference between the returns for the event firms and control firms in the same time period. 
FIGURE 2

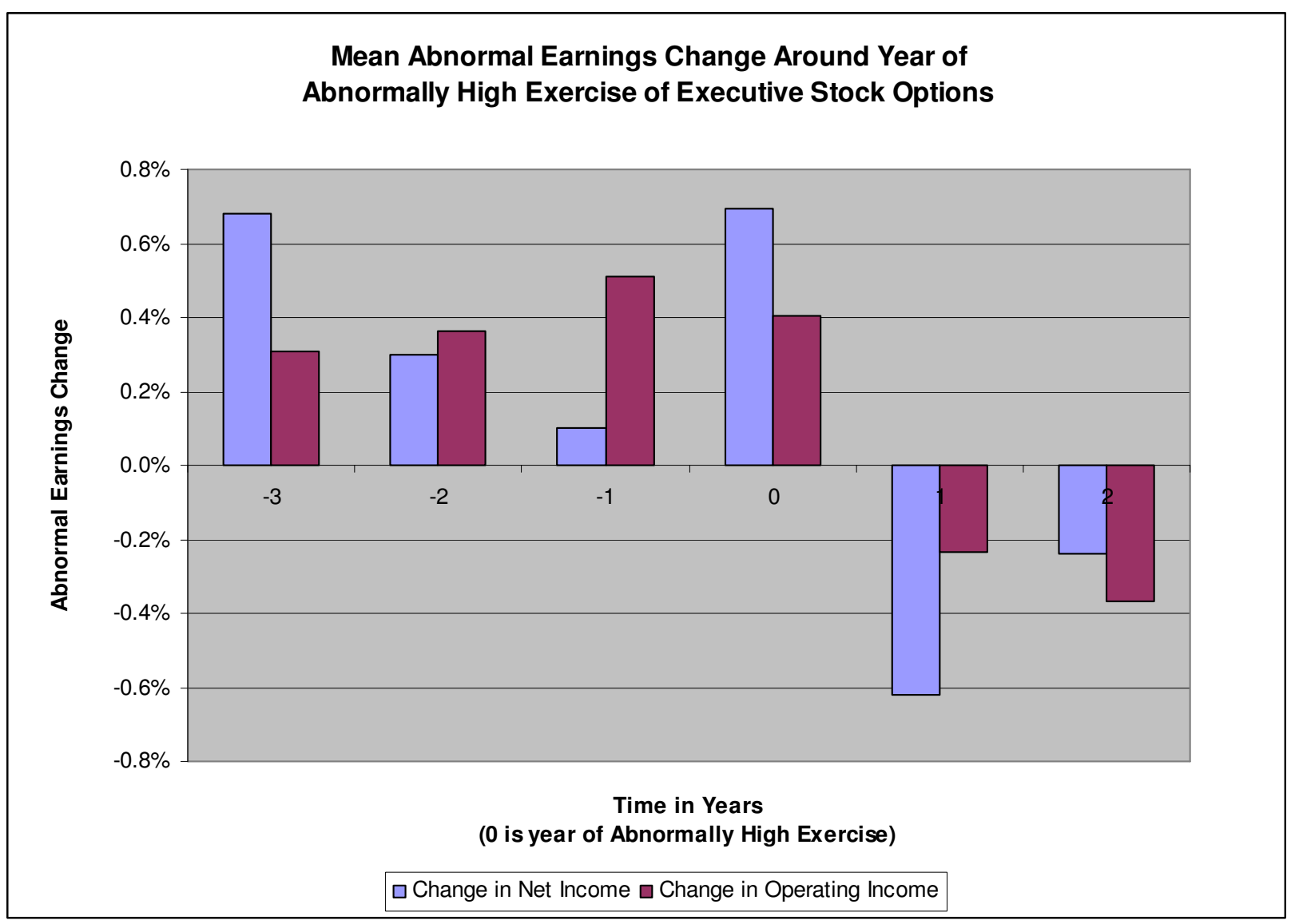

The size of option exercises is measured as the proportion of compensation from stock option exercise, averaged across the top 5 highest compensated executives. Abnormally large exercises are identified by examining the ratio of this proportion with the average from the past (up to three years). Firms for which there was a greater than 50\% increase in this ratio are classified as having abnormally large exercises. These firms are matched at the exercise year (year 0) to the closest firm in size (measured by market capitalization) in the same industry (2-digit SIC code), belonging to the same return quintile in year -1 , that did not have an abnormally large exercise. The change in Net Income before Extra-ordinary Items (Compustat data item \#18) and change in Operating Income (Compustat data item \#13) are scaled by beginning total assets. Abnormal Earnings Changes are the difference between the earnings changes for the event firms and the control firms in the same time period. 
FIGURE 3

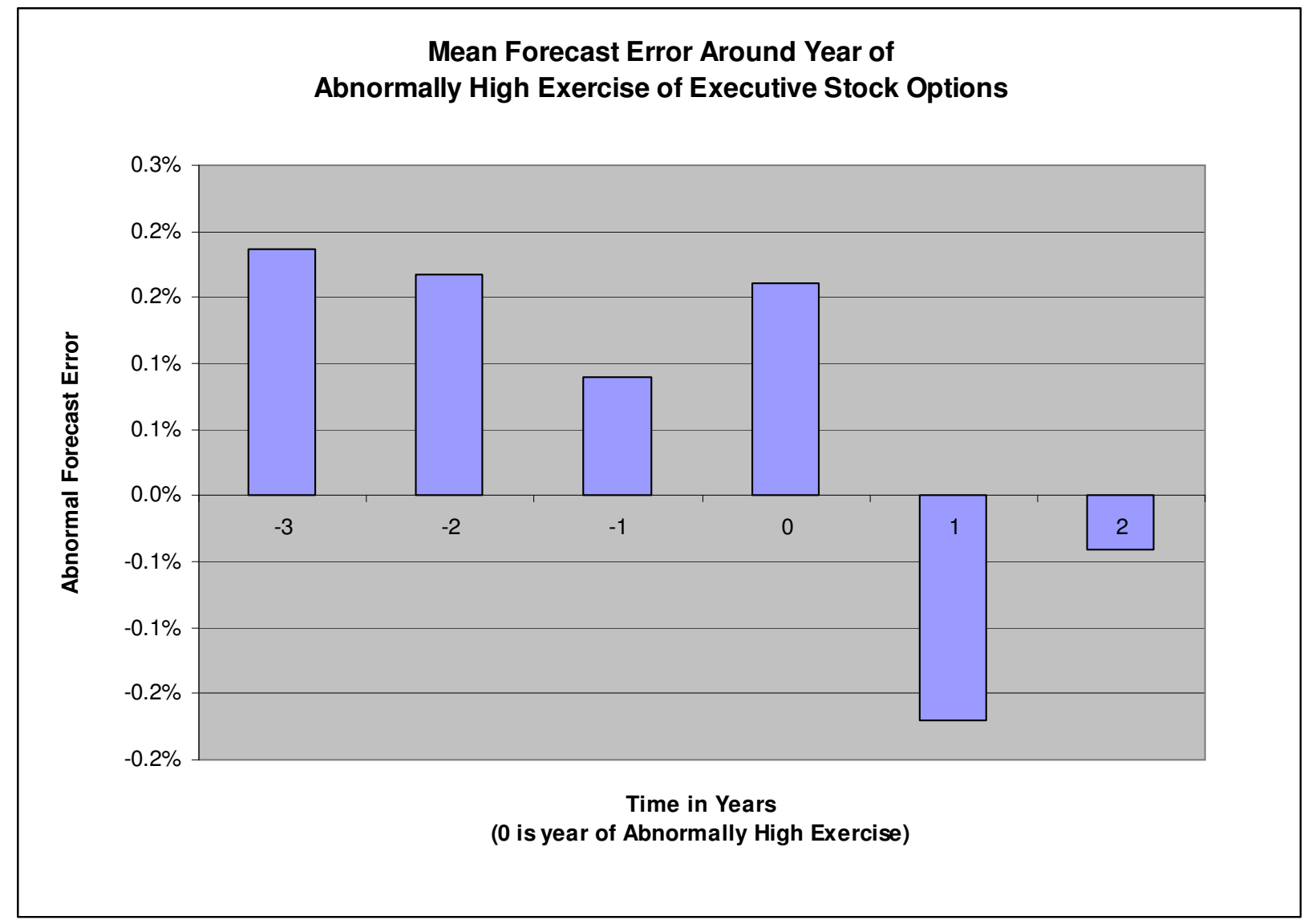

The size of option exercises is measured as the proportion of compensation from stock option exercise, averaged across the top 5 highest compensated executives. Abnormally large exercises are identified by examining the ratio of this proportion with the average from the past (up to three years). Firms for which there was a greater than $50 \%$ increase in this ratio are classified as having abnormally large exercises. These firms are matched at the exercise year (year 0) to the closest firm in size (measured by market capitalization) in the same industry (2-digit SIC code), belonging to the same return quintile in year -1, that did not have an abnormally large exercise. Forecast Error is the difference between actual reported EPS and forecasted EPS, scaled by price at the time of the forecast. 
FIGURE 4-A

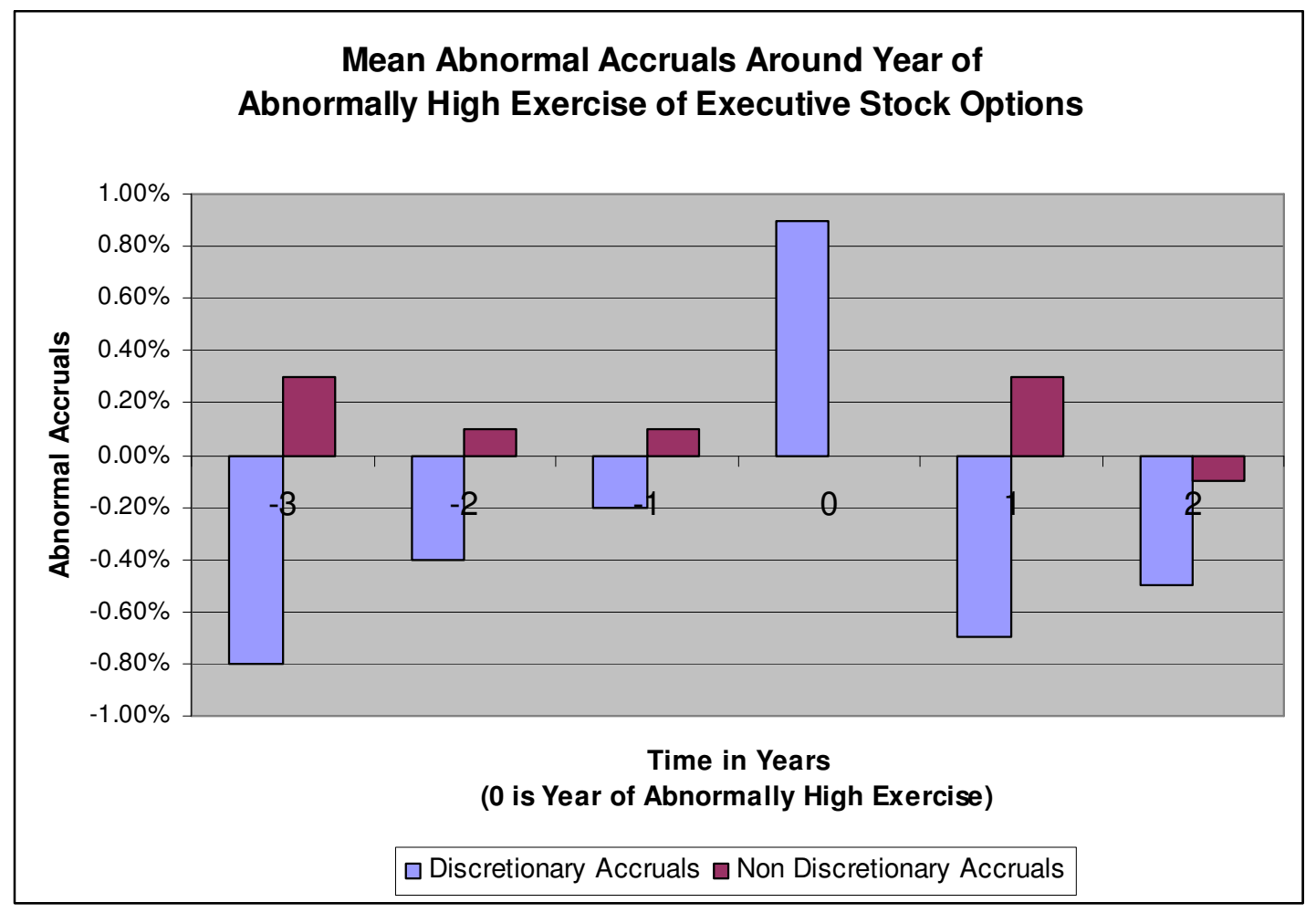

FIGURE 4-B

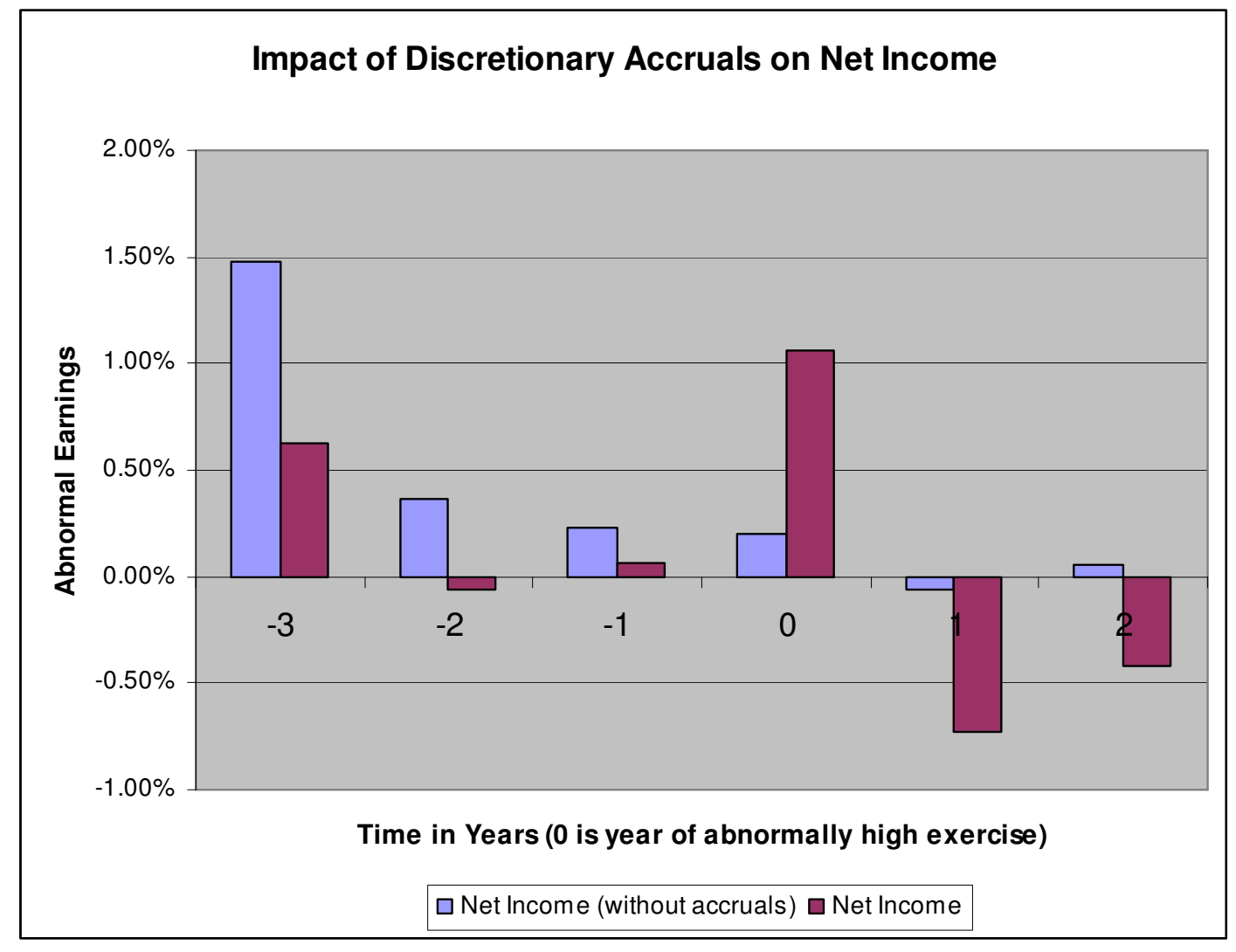


The size of option exercises is measured as the proportion of compensation from stock option exercise, averaged across the top 5 highest compensated executives. Abnormally large exercises are identified by examining the ratio of this proportion with the average from the past (up to three years). Firms for which there was a greater than $50 \%$ increase in this ratio are classified as having abnormally large exercises. These firms are matched at the exercise year (year 0) to the closest firm in size (measured by market capitalization) in the same industry (2-digit SIC code), belonging to the same return quintile in year -1 , that did not have an abnormally large exercise. Discretionary Accruals are measured as the difference between the total accruals and fitted values from cross-sectional performance adjusted Jones model using lagged information. Abnormal Accruals are the difference between the accrual measures for the event firms and control firms in the same time period. In Figure B, Net income before extraordinary items is measured first as defined and second by removing discretionary accruals. Abnormal earnings are the difference between earnings for sample firms and control firms. 


\section{TABLE 1}

Sample Selection

\begin{tabular}{|c|c|c|}
\hline CRITERION & $\begin{array}{l}\text { Number of } \\
\text { Firm Years }\end{array}$ & $\begin{array}{l}\text { Number of } \\
\text { Distinct Firms }\end{array}$ \\
\hline Compensation data available on EXECUCOMP (1992-2001) & 17,970 & 2,507 \\
\hline LESS Observations without required lagged data to compare past option exercise & $\underline{6,413}$ & $\underline{343}$ \\
\hline Compensation data available on EXECUCOMP with lagged compensation data & 11,557 & 2,164 \\
\hline LESS observations with exercise below cutoff & $\underline{7,829}$ & $\underline{387}$ \\
\hline $\begin{array}{l}\text { Abnormally large executive option exercise with data available on } \\
\text { EXECUCOMP }\end{array}$ & 3,728 & 1,777 \\
\hline $\begin{array}{l}\text { LESS observations deleted because they are less than three years apart, beginning } \\
\text { from earliest occurrence }\end{array}$ & $\underline{1,727}$ & $\underline{0}$ \\
\hline $\begin{array}{l}\text { Abnormally large executive option exercise with data available on } \\
\text { EXECUCOMP at least three years apart from same firm observations }\end{array}$ & 2,001 & 1,777 \\
\hline LESS control firm unavailable & 427 & $\underline{343}$ \\
\hline $\begin{array}{l}\text { Matched abnormally large executive option exercise with data available on } \\
\text { EXECUCOMP, that are more than three years apart }\end{array}$ & 1,574 & 1,434 \\
\hline $\begin{array}{l}\text { LESS, missing return data on CRSP in any of the four years }(-2,+1) \text {, where year } \\
0 \text { is the exercise year }\end{array}$ & $\underline{252}$ & $\underline{216}$ \\
\hline FINAL SAMPLE & 1,322 & 1,218 \\
\hline
\end{tabular}


TABLE 2

Industry and Time Sample Distribution

Panel A: Industry Distribution

\begin{tabular}{llcc}
\hline SIC & DESCRIPTION & $\begin{array}{c}\text { Number } \\
\text { of Firms }\end{array}$ & $\begin{array}{c}\% \text { of } \\
\text { Sample }\end{array}$ \\
\hline 13 & Oil and gas extraction & 53 & $4.0 \%$ \\
20 & Food and kindred products & 26 & $2.0 \%$ \\
26 & Paper and allied products & 18 & $1.4 \%$ \\
27 & Printing and publishing & 22 & $1.7 \%$ \\
28 & Chemicals and allied products & 111 & $8.4 \%$ \\
29 & Petroleum and coal products & 11 & $0.8 \%$ \\
33 & Primary metal industries & 29 & $2.2 \%$ \\
34 & Fabricated metal products & 17 & $1.3 \%$ \\
35 & Industrial machinery and equipment & 103 & $7.8 \%$ \\
36 & Electronic \& other electric equipment & 121 & $9.2 \%$ \\
37 & Transportation equipment & 35 & $2.6 \%$ \\
38 & Instruments and related products & 86 & $6.5 \%$ \\
48 & Communication & 36 & $2.7 \%$ \\
49 & Electric, gas, and sanitary services & 80 & $6.1 \%$ \\
50 & Wholesale trade-durable goods & 29 & $2.2 \%$ \\
51 & Wholesale trade-nondurable goods & 16 & $1.2 \%$ \\
53 & General merchandise stores & 10 & $0.8 \%$ \\
56 & Apparel and accessory stores & 20 & $1.5 \%$ \\
58 & Eating and drinking places & 17 & $1.3 \%$ \\
59 & Miscellaneous retail & 21 & $1.6 \%$ \\
60 & Depository institutions & 113 & $8.5 \%$ \\
62 & Security and commodity brokers & 13 & $1.0 \%$ \\
63 & Insurance carriers & 64 & $4.8 \%$ \\
73 & Business services & 132 & $10.0 \%$ \\
80 & Health services & 17 & $1.3 \%$ \\
& ALL OTHER INDUSTRIES & 122 & $9.2 \%$ \\
\hline & & &
\end{tabular}

Panel B: Time Distribution

\begin{tabular}{lcc}
\hline YEAR & $\begin{array}{l}\text { Number of } \\
\text { Firms }\end{array}$ & $\begin{array}{l}\text { \% of } \\
\text { Sample }\end{array}$ \\
\hline 1993 & 197 & $14.9 \%$ \\
1994 & 151 & $11.4 \%$ \\
1995 & 160 & $12.1 \%$ \\
1996 & 201 & $15.2 \%$ \\
1997 & 205 & $15.5 \%$ \\
1998 & 165 & $12.5 \%$ \\
1999 & 101 & $7.6 \%$ \\
2000 & 80 & $6.1 \%$ \\
2001 & 62 & $4.7 \%$ \\
\hline
\end{tabular}


TABLE 3

Descriptive Statistics

Panel A: Comparison of Test Firms and Control Firms in the Event Year

\begin{tabular}{|c|c|c|c|c|c|c|}
\hline \multirow[b]{2}{*}{ Variable } & \multicolumn{3}{|c|}{ MEANS } & \multicolumn{3}{|c|}{ MEDIANS } \\
\hline & $\begin{array}{l}\text { TEST } \\
\text { FIRM }\end{array}$ & $\begin{array}{l}\text { CONTROL } \\
\text { FIRM }\end{array}$ & $\begin{array}{l}\text { Difference } \\
\text { (t-stat) }\end{array}$ & $\begin{array}{l}\text { TEST } \\
\text { FIRM }\end{array}$ & $\begin{array}{l}\text { CONTROL } \\
\text { FIRM }\end{array}$ & $\begin{array}{l}\text { Difference } \\
\text { (z-stat) }\end{array}$ \\
\hline Market Capitalization (\$ Millions) & 4413 & 3540 & $\begin{array}{l}873 \\
(2.01)^{* *}\end{array}$ & 1187 & 1012 & $\begin{array}{l}175 \\
(1.57)\end{array}$ \\
\hline Sales (\$millions) & 3005 & 2794 & $\begin{array}{l}211 \\
(1.24)\end{array}$ & 826 & 784 & $\begin{array}{l}40 \\
(0.36)\end{array}$ \\
\hline Assets (\$millions) & 7432 & 6191 & $\begin{array}{l}1241 \\
(1.07)\end{array}$ & 1020 & 1015 & $\begin{array}{l}5 \\
(0.15)\end{array}$ \\
\hline $\begin{array}{l}\% \text { Compensation from Stock Option } \\
\text { Exercise (top } 5 \text { compensated executives) }\end{array}$ & $29.1 \%$ & $7.4 \%$ & $\begin{array}{l}21.7 \% \\
(31.93)^{* * *}\end{array}$ & $24.2 \%$ & $0 \%$ & $\begin{array}{l}24.2 \% \\
(29.19)^{* * *}\end{array}$ \\
\hline $\begin{array}{l}\text { Amount from Stock Option Exercise } \\
\text { (\$millions) (top } 5 \text { compensated executives) }\end{array}$ & 5.59 & 0.91 & $\begin{array}{l}4.68 \\
(10.36)^{* * *}\end{array}$ & 1.67 & 0 & $\begin{array}{l}1.67 \\
(21.47)^{* * *}\end{array}$ \\
\hline
\end{tabular}

Panel B: Comparison of Test Firms in Event and Nonevent Years

\begin{tabular}{l|lll|lll}
\hline & \multicolumn{3}{|c|}{ MEANS } & \multicolumn{3}{c}{ MEDIANS } \\
\hline Variable & $\begin{array}{l}\text { EVENT } \\
\text { PERIOD }\end{array}$ & $\begin{array}{l}\text { NON- } \\
\text { EVENT } \\
\text { PERIOD }\end{array}$ & $\begin{array}{l}\text { Difference } \\
\text { (t-stat) }\end{array}$ & $\begin{array}{l}\text { EVENT } \\
\text { PERIOD }\end{array}$ & $\begin{array}{l}\text { NON- } \\
\text { EVENT } \\
\text { PERIOD }\end{array}$ & $\begin{array}{l}\text { Difference } \\
\text { (z-stat) }\end{array}$ \\
\hline$\%$ Compensation from Stock Option & $29.1 \%$ & $9.1 \%$ & $\begin{array}{l}20.0 \% \\
(32.59)^{* * *}\end{array}$ & $24.2 \%$ & $3.7 \%$ & $\begin{array}{l}20.5 \% \\
(35.54)^{* * *}\end{array}$ \\
$\begin{array}{l}\text { Exercise (top 5 compensated executives) } \\
\text { Amount from Stock Option Exercise } \\
\text { (\$millions) (top 5 compensated executives) }\end{array}$ & 5.59 & 1.15 & $\begin{array}{l}4.44 \\
(9.86)^{* * *}\end{array}$ & 1.67 & 0.10 & 1.57 \\
\hline
\end{tabular}

Panel C: Comparison of Option Exercise and Sale of Stock by CEO / Chairman in the Event Year

\begin{tabular}{|c|c|c|c|c|c|c|}
\hline & \multicolumn{3}{|c|}{ MEANS } & \multicolumn{3}{|c|}{ MEDIANS } \\
\hline Variable & $\begin{array}{l}\text { EVENT } \\
\text { PERIOD }\end{array}$ & $\begin{array}{l}\text { NON- } \\
\text { EVENT } \\
\text { PERIOD }\end{array}$ & $\begin{array}{l}\text { Difference } \\
\text { (t-stat) }\end{array}$ & $\begin{array}{l}\text { EVENT } \\
\text { PERIOD }\end{array}$ & $\begin{array}{l}\text { NON- } \\
\text { EVENT } \\
\text { PERIOD }\end{array}$ & $\begin{array}{l}\text { Difference } \\
\text { (z-stat) }\end{array}$ \\
\hline Proceeds of Stock Option Exercise (\$millions) & 3.85 & 1.15 & $\begin{array}{l}2.70 \\
(8.03)^{* * *}\end{array}$ & 0.76 & 0.00 & $\begin{array}{l}0.76 \\
(5.06)^{* * *}\end{array}$ \\
\hline Proceeds of Sale of Stock (\$millions) & 8.64 & 5.57 & $\begin{array}{l}3.07 \\
(3.91)^{* * *}\end{array}$ & 2.36 & 1.03 & $\begin{array}{l}1.33 \\
(3.48)^{* * *}\end{array}$ \\
\hline
\end{tabular}

The size of option exercises is measured as the proportion of compensation from stock option exercise, averaged across the top 5 highest compensated executives. Abnormally large exercises are identified by examining the ratio of this proportion with the average from the past (up to three years). Firms for which there was a greater than $50 \%$ increase in this ratio are classified as having abnormally large exercises. These firms are matched at the exercise year (year 0 ) to the closest firm in size (measured by market capitalization) in the same industry (2-digit SIC code), belonging to the same return quintile in year -1, that did not have an abnormally large exercise. Sales, Assets, and Amount from Stock Exercise are all in \$million. Assets are total assets as of fiscal-year end (Compustat data item \# 6), and sales is total net annual sales (Compustat data item \# 12).

Panel A compares 1,322 event-years with corresponding control years. Panel B compares 1,322 event-years with 3,169 nonevent years in the three years prior to the event year for test firms. For Panels A and B, the amount from stock option exercise is the dollar amount that executives earned from exercise of stock options (difference between exercise price and stock price on day of exercise times number of options exercised summed across the year) and is summed across top five compensated employees. Proportion of compensation from stock exercise is the proportion of total compensation including option exercise (the variable TDC2 in EXECUCOMP) from the exercise of stock options, and is averaged across the top 5 compensated employees. In Panel $\mathrm{C}$, the amount from sale of stock is calculated from data obtained from Thomson Financial's Insider Trading database for the subset of firms for which data was available (774 out of 1,322). This is compared to 1,341 non-event years in the three years prior to the event year for the test firms. The unit of aggregation was CEO and/or Chairman as these identifiers were clearly available on both EXECUCOMP as well as Thomson Financial, while there was no reliable way of linking the top 5 compensated executives on EXECUCOMP with Thomson Financial. t-statistic/z-statistic is for pooled difference of means/Wilcoxon sign-rank test.

Significant at ${ }^{* * *} 1 \%$ level ${ }^{* *} 5 \%$ level $\quad{ }^{*} 10 \%$ level using a 2 tailed test 
TABLE 4

Stock Returns around Abnormally Large Option Exercises

Panel A: Annual Returns

\begin{tabular}{|c|c|c|c|c|c|}
\hline \multirow[b]{2}{*}{ YEAR } & \multirow[b]{2}{*}{$\mathrm{N}$} & \multicolumn{2}{|c|}{ MEAN RAW RETURNS } & \multicolumn{2}{|c|}{$\begin{array}{l}\text { MEAN ABNORMAL } \\
\text { RETURNS }\end{array}$} \\
\hline & & Test Firms & $\begin{array}{l}\text { Control } \\
\text { Firms }\end{array}$ & $\begin{array}{l}\text { Test minus } \\
\text { Control }\end{array}$ & t-stat \\
\hline-3 & 1147 & $20.4 \%$ & $20.4 \%$ & $0.0 \%$ & 0.02 \\
\hline-2 & 1322 & $31.6 \%$ & $21.6 \%$ & $10.0 \%$ & $4.29^{* * * *}$ \\
\hline-1 & 1322 & $45.3 \%$ & $45.8 \%$ & $-0.5 \%$ & -0.26 \\
\hline 0 & 1322 & $35.4 \%$ & $26.2 \%$ & $9.2 \%$ & $2.98^{* * * *}$ \\
\hline 1 & 1322 & $15.1 \%$ & $26.3 \%$ & $-11.2 \%$ & $-4.40^{* * *}$ \\
\hline 2 & 1149 & $17.3 \%$ & $19.9 \%$ & $-2.6 \%$ & -0.90 \\
\hline Average over $(-1,0)$ & 2644 & $40.4 \%$ & $36.0 \%$ & $4.4 \%$ & \\
\hline Average over $(+1,+2)$ & 2471 & $16.1 \%$ & $23.3 \%$ & $-7.2 \%$ & \\
\hline $\begin{array}{l}\text { Change } \\
\text { (t-stat) }\end{array}$ & & $\begin{array}{l}-24.2 \% \\
(-11.17)^{* * *}\end{array}$ & $\begin{array}{l}-12.7 \% \\
(-5.47)^{* * * *}\end{array}$ & $\begin{array}{l}-11.6 \% \\
(-4.36)^{* * *}\end{array}$ & \\
\hline
\end{tabular}

Panel B: Annual Returns Partitioned by Firm Size (Market Capitalization)

\begin{tabular}{l|lll|lll|lll}
\hline & \multicolumn{3}{|c|}{ SMALL FIRMS } & \multicolumn{3}{c|}{ MEDIUM FIRMS } & \multicolumn{3}{c}{ LARGE FIRMS } \\
\hline YEAR & $\mathrm{N}$ & $\begin{array}{l}\text { Test } \\
\text { minus } \\
\text { Control }\end{array}$ & t-stat & N & $\begin{array}{l}\text { Test } \\
\text { minus } \\
\text { Control }\end{array}$ & t-stat & N & \multicolumn{3}{c}{$\begin{array}{l}\text { Test } \\
\text { minus } \\
\text { Control }\end{array}$} & t-stat \\
\hline-3 & 38 & $-33.7 \%$ & $-2.57^{* * *}$ & 262 & $-3.1 \%$ & -0.61 & 847 & $2.5 \%$ & 0.99 \\
-2 & 50 & $-6.7 \%$ & -0.73 & 306 & $11.9 \%$ & $2.07^{* *}$ & 966 & $10.2 \%$ & $3.99^{* * *}$ \\
-1 & 50 & $-12.0 \%$ & -0.54 & 306 & $-0.3 \%$ & -0.05 & 966 & $0.0 \%$ & 0.00 \\
0 & 50 & $50.1 \%$ & $3.97^{* * *}$ & 306 & $19.3 \%$ & $2.03^{* *}$ & 966 & $3.9 \%$ & $1.78^{*}$ \\
1 & 50 & $-22.3 \%$ & $-1.91^{*}$ & 306 & $-11.3 \%$ & $-1.75^{*}$ & 966 & $-10.6 \%$ & $-3.92^{* * *}$ \\
2 & 41 & $22.3 \%$ & 0.81 & 254 & $-3.6 \%$ & -0.60 & 854 & $-3.5 \%$ & -1.09 \\
\hline
\end{tabular}

Panel C: Full Sample Partitioned by Subperiods

\begin{tabular}{|c|c|c|c|c|c|c|c|c|c|}
\hline \multirow[b]{2}{*}{ YEAR } & \multicolumn{3}{|c|}{ 1993-1996 } & \multicolumn{3}{|c|}{ 1997-1999 } & \multicolumn{3}{|c|}{$2000-2001$} \\
\hline & $\mathrm{N}$ & $\begin{array}{l}\text { Test } \\
\text { minus } \\
\text { Control }\end{array}$ & t-stat & $\mathrm{N}$ & $\begin{array}{l}\text { Test } \\
\text { minus } \\
\text { Control }\end{array}$ & t-stat & $\mathrm{N}$ & $\begin{array}{l}\text { est } \\
\text { ninus } \\
\text { Control }\end{array}$ & t-stat \\
\hline-3 & 629 & $0.8 \%$ & 0.30 & 394 & $-0.3 \%$ & -0.06 & 124 & $-2.4 \%$ & -0.44 \\
\hline-2 & 709 & $6.8 \%$ & $2.48^{* *}$ & 471 & $15.6 \%$ & $3.75^{* * *}$ & 142 & $7.2 \%$ & 0.75 \\
\hline-1 & 709 & $-3.3 \%$ & -1.59 & 471 & $1.8 \%$ & 0.57 & 142 & $5.8 \%$ & 0.56 \\
\hline 0 & 709 & $6.3 \%$ & $1.91^{*}$ & 471 & $17.9 \%$ & $2.57^{* *}$ & 142 & $15.1 \%$ & $2.45^{* *}$ \\
\hline 1 & 709 & $-6.1 \%$ & $-2.62^{* * *}$ & 471 & $-19.3 \%$ & $-3.18^{* * * *}$ & 142 & $-9.8 \%$ & $-2.31^{* *}$ \\
\hline 2 & 656 & $-0.5 \%$ & -0.19 & 420 & $-5.5 \%$ & -0.85 & 73 & $-4.4 \%$ & -1.01 \\
\hline
\end{tabular}


Panel D: Computing Excess Returns Using the 4-factor Model

\begin{tabular}{l|l|l|l|lc}
\hline & & \multicolumn{4}{|c}{$\begin{array}{c}\text { MEAN MONTHLY ABNORMAL } \\
\text { RETURN }(\alpha)\end{array}$} \\
\hline \multicolumn{1}{c|}{ YEAR } & $\mathrm{N}$ & \multicolumn{1}{|c|}{ Test Firms } & Control Firms & $\begin{array}{c}\text { Test minus } \\
\text { Control }\end{array}$ & t-stat \\
\hline-3 & 1147 & $0.72 \%$ & $0.33 \%$ & $0.39 \%$ & $1.80^{*}$ \\
-2 & 1322 & $0.78 \%$ & $0.39 \%$ & $0.38 \%$ & $1.78^{*}$ \\
-1 & 1322 & $0.90 \%$ & $1.33 \%$ & $-0.43 \%$ & $-1.67^{*}$ \\
0 & 1322 & $1.34 \%$ & $0.80 \%$ & $0.54 \%$ & $2.43^{* *}$ \\
1 & 1322 & $0.40 \%$ & $0.82 \%$ & $-0.42 \%$ & $-1.71^{*}$ \\
2 & 1149 & $0.33 \%$ & $1.03 \%$ & $-0.69 \%$ & $-2.40^{* * *}$ \\
\hline Average over $(-1,0)$ & 2644 & $1.12 \%$ & $1.06 \%$ & $0.06 \%$ & \\
Average over $(+1,+2)$ & 2471 & $0.37 \%$ & $0.93 \%$ & $-0.56 \%$ & \\
Change & & $-0.75 \%$ & $-0.14 \%$ & $-0.62 \%$ & \\
(t-stat) & & $\left(-4.27^{* * * *}\right)$ & $(-1.07)$ & $\left(-2.71^{* * *}\right)$ & \\
\hline
\end{tabular}

Panel E: Annual Returns for All Exercises from 1992-1995 (replication of Carpenter and Remmers 2001)

\begin{tabular}{c|l|lc|}
\hline YEAR & N & $\begin{array}{l}\text { SIZE ADJUSTED } \\
\text { RETURNS }\end{array}$ & t-stat \\
\hline-3 & 3,414 & $14.8 \%$ & $10.19^{* * * *}$ \\
-2 & 3,544 & $17.5 \%$ & $11.08^{* * *}$ \\
-1 & 3,544 & $18.0 \%$ & $10.97^{* * *}$ \\
0 & 3,544 & $10.4 \%$ & $9.16^{* * *}$ \\
1 & 3,544 & $2.1 \%$ & $2.14^{* *}$ \\
2 & 3,493 & $1.4 \%$ & 1.38 \\
\hline
\end{tabular}

The size of option exercises is measured as the proportion of compensation from stock option exercise, averaged across the top 5 highest compensated executives. Abnormally large exercises are identified by examining the ratio of this proportion with the average from the past (up to three years). Firms for which there was a greater than 50\% increase in this ratio are classified as having abnormally large exercises. These firms are matched at the exercise year (year 0) to the closest firm in size (measured by market capitalization) in the same industry (2-digit SIC code), belonging to the same return quintile in year -1 , that did not have an abnormally large exercise. Returns are buyand-hold annual raw returns around abnormally large option exercise year (year 0). Annual returns are measured over the fiscal year and constructed from monthly returns. $\mathrm{N}$ is the number of test firms. In Panel $\mathrm{B}$, firms are categorized as small, medium or large on the basis of their CRSP capitalization decile. Small firms are those in groups 1-6, medium firms in groups 7-8; large firms in groups 9 and 10. Panel $\mathrm{C}$ partitions the sample on the basis of calendar time of abnormally high exercise. In panel D, monthly excess returns are calculated for event firms and control firms using the Carhart's (1997) 4-factor model. The intercept, $\alpha$, from the 4-factor model--which controls for market risk premium $\left(\mathrm{R}_{\mathrm{m}}-\mathrm{R}_{\mathrm{f}}\right.$ ), firm size (SMB), book to market (HML), and return momentum (UMD)--is used as the measure of excess return. Regressions are carried out by year at the firm level using monthly returns. The distribution of monthly $\alpha$ across firms in event time is used to calculate t-statistics. Panel E replicates Carpenters and Remmers (2001) by analyzing returns around all option exercises from 1992-95. Returns are annual buy and hold returns, which are size adjusted by subtracting returns of the CRSP capitalization decile to which the firm belongs. t-statistics for the mean differences are from 2 sample t-tests. For all the analyses, all firm-years have complete information from years, -2 to +1 . Some firm-years do not have information for year -3 or +2 . $\mathrm{N}$ is the number of test firms (and correspondingly, control firms).

Significant at ${ }^{* * * *} 1 \%$ level ${ }_{* *}^{*} 5 \%$ level ${ }^{*} 10 \%$ level using a 2 tailed test 
TABLE 5

Earnings Changes around Abnormally Large Option Exercises

\begin{tabular}{|c|c|c|c|c|c|c|c|c|c|}
\hline \multirow[b]{2}{*}{ YEAR } & \multirow[b]{2}{*}{$\mathrm{N}$} & \multicolumn{4}{|c|}{$\begin{array}{c}\text { MEAN CHANGE IN INCOME } \\
\text { BEFORE EXTRA-ORDINARY ITEMS }\end{array}$} & \multicolumn{4}{|c|}{$\begin{array}{l}\text { MEAN CHANGE IN } \\
\text { OPERATING INCOME }\end{array}$} \\
\hline & & $\begin{array}{l}\text { Test } \\
\text { Firms }\end{array}$ & $\begin{array}{l}\text { Control } \\
\text { Firms }\end{array}$ & $\begin{array}{l}\text { Test } \\
\text { minus } \\
\text { Control } \\
\end{array}$ & t-stat & $\begin{array}{l}\text { Test } \\
\text { Firms }\end{array}$ & $\begin{array}{l}\text { Control } \\
\text { Firms }\end{array}$ & $\begin{array}{l}\text { Test } \\
\text { minus } \\
\text { Control } \\
\end{array}$ & t-stat \\
\hline-3 & 882 & $1.4 \%$ & $0.7 \%$ & $0.7 \%$ & $1.77^{*}$ & $2.9 \%$ & $2.5 \%$ & $0.3 \%$ & 1.33 \\
\hline-2 & 1045 & $1.8 \%$ & $1.5 \%$ & $0.3 \%$ & 0.83 & $3.3 \%$ & $3.0 \%$ & $0.4 \%$ & $1.76^{*}$ \\
\hline-1 & 1045 & $1.9 \%$ & $1.8 \%$ & $0.1 \%$ & 0.31 & $3.7 \%$ & $3.2 \%$ & $0.5 \%$ & $2.65^{* * * *}$ \\
\hline 0 & 1045 & $2.0 \%$ & $1.3 \%$ & $0.7 \%$ & $1.93^{*}$ & $4.0 \%$ & $3.6 \%$ & $0.4 \%$ & $2.03^{* *}$ \\
\hline 1 & 1045 & $0.7 \%$ & $1.3 \%$ & $-0.6 \%$ & $-1.74^{*}$ & $2.7 \%$ & $3.0 \%$ & $-0.2 \%$ & -1.22 \\
\hline 2 & 888 & $0.4 \%$ & $0.6 \%$ & $-0.2 \%$ & -0.60 & $1.8 \%$ & $2.1 \%$ & $-0.4 \%$ & $-1.75^{*}$ \\
\hline $\begin{array}{l}\text { Average over } \\
(-1,0) \\
\text { Average over }\end{array}$ & 1852 & 2090 & $2.0 \%$ & $1.5 \%$ & $0.4 \%$ & $3.9 \%$ & $3.4 \%$ & $0.5 \%$ & \\
\hline $\begin{array}{l}(+1,+2) \\
\text { Change } \\
\text { ( t-stat) }\end{array}$ & 1687 & 1933 & $\begin{array}{l}0.5 \% \\
-1.4 \% \\
(-5.44)^{* * *}\end{array}$ & $\begin{array}{l}1.0 \% \\
-0.5 \% \\
(-1.88)\end{array}$ & $\begin{array}{l}-0.4 \% \\
-0.8 \% \\
(-2.34)^{* *}\end{array}$ & $\begin{array}{l}2.3 \% \\
-1.6 \% \\
(-6.33)^{* * *}\end{array}$ & $\begin{array}{l}2.6 \% \\
-0.8 \% \\
(-3.16)^{* * *}\end{array}$ & $\begin{array}{l}-0.3 \% \\
-0.8 \% \\
(-2.37)^{* * *}\end{array}$ & \\
\hline
\end{tabular}

The size of option exercises is measured as the proportion of compensation from stock option exercise, averaged across the top 5 highest compensated executives. Abnormally large exercises are identified by examining the ratio of this proportion with the average from the past (up to three years). Firms for which there was a greater than 50\% increase in this ratio are classified as having abnormally large exercises. These firms are matched at the exercise year (year 0) to the closest firm in size (measured by market capitalization) in the same industry (2-digit SIC code), belonging to the same return quintile in year -1 , that did not have an abnormally large exercise. The change in net income before extra-ordinary items (Compustat data item \#18) and change in operating income (Compustat data item \#13) are scaled by beginning total assets. t-statistics for the mean differences are from 2 sample t-tests. All firm-years have complete information from years, -2 to +1 . Some firm-years do not have information for year -3 or +2 . $\mathrm{N}$ is the number of test firms (and correspondingly, control firms).

Significant at ${ }^{* * *} 1 \%$ level ${ }^{* *} 5 \%$ level ${ }^{*} 10 \%$ level using a 2 tailed test 
TABLE 6

Analyst Earnings Forecast Errors around Abnormally Large Option Exercises

\begin{tabular}{l|l|llll|llll}
\hline & & \multicolumn{9}{|c|}{ MEAN SCALED FORECAST ERROR } & \multicolumn{3}{c}{ MEAN UNSCALED FORECAST ERROR } \\
\hline YEAR & $\mathrm{N}$ & $\begin{array}{l}\text { Test } \\
\text { Firms }\end{array}$ & $\begin{array}{l}\text { Control } \\
\text { Firms }\end{array}$ & $\begin{array}{l}\text { Test minus } \\
\text { Control }\end{array}$ & t-stat & Test Firms & $\begin{array}{l}\text { Control } \\
\text { Firms }\end{array}$ & $\begin{array}{l}\text { Test } \\
\text { minus } \\
\text { Control }\end{array}$ & t-stat \\
\hline-3 & 850 & $-0.8 \%$ & $-1.1 \%$ & $0.2 \%$ & 1.31 & -0.13 & -0.13 & 0.00 & -0.04 \\
-2 & 1010 & $-0.5 \%$ & $-0.7 \%$ & $0.2 \%$ & 1.39 & -0.09 & -0.09 & 0.00 & 0.43 \\
-1 & 1010 & $-0.3 \%$ & $-0.4 \%$ & $0.1 \%$ & 0.85 & -0.06 & -0.05 & -0.01 & -1.05 \\
0 & 1010 & $-0.3 \%$ & $-0.4 \%$ & $0.2 \%$ & $1.74^{*}$ & -0.05 & -0.07 & 0.02 & $1.71^{*}$ \\
1 & 1010 & $-0.6 \%$ & $-0.4 \%$ & $-0.2 \%$ & $-1.69^{*}$ & -0.12 & -0.09 & -0.03 & $-2.26^{* *}$ \\
2 & 862 & $-0.8 \%$ & $-0.7 \%$ & $0.0 \%$ & -0.31 & -0.15 & -0.13 & -0.02 & $-1.69^{*}$ \\
& & & & & & & & & \\
\hline$(-1,0)$ & 2020 & $-0.3 \%$ & $-0.4 \%$ & $0.1 \%$ & & -0.060 & -0.060 & 0.005 & 2020 \\
$(+1,+2)$ & 1872 & $-0.7 \%$ & $-0.6 \%$ & $-0.1 \%$ & & -0.132 & -0.108 & -0.025 & 1872 \\
Change & & $-0.4 \%$ & $-0.2 \%$ & $-0.2 \%$ & & -0.071 & -0.049 & -0.030 & \\
$(\mathrm{t}-$-stat) & & $(-5.04)^{* * * *}$ & $(-2.54)^{* *}$ & $(-1.70)^{*}$ & & $(-5.17)^{* * *}$ & $(-3.71)^{* * * *}$ & $(-1.72)^{*}$ & \\
\hline
\end{tabular}

The size of option exercises is measured as the proportion of compensation from stock option exercise, averaged across the top 5 highest compensated executives. Abnormally large exercises are identified by examining the ratio of this proportion with the average from the past (up to three years). Firms for which there was a greater than 50\% increase in this ratio are classified as having abnormally large exercises. These firms are matched at the exercise year (year 0) to the closest firm in size (measured by market capitalization) in the same industry (2-digit SIC code), belonging to the same return quintile in year -1 , that did not have an abnormally large exercise. Forecast error is the difference between actual EPS and the forecasted EPS obtained from IBES after the end of the fourth month of the prior fiscal year, scaled by price at the time of the forecast. Unscaled forecast error is merely the difference in actual and forecasted EPS without any deflation. $\mathrm{t}$-statistics for the mean differences are from 2 sample $\mathrm{t}$-tests. All firmyears have complete information from years, -2 to +1 . Some firm-years do not have information for year -3 or +2 . $\mathrm{N}$ is the number of test firms (and correspondingly, control firms).

Significant at ${ }^{* * *} 1 \%$ level ${ }^{* *} 5 \%$ level ${ }^{*} 10 \%$ level using a 2 tailed test 


\section{TABLE 7}

\section{Accruals around Abnormally Large Option Exercise}

Panel A: Comparison of Discretionary and Non-Discretionary Accruals across Time

\begin{tabular}{|c|c|c|c|c|c|c|c|c|c|}
\hline \multirow[b]{2}{*}{ YEAR } & \multirow[b]{2}{*}{$\mathrm{N}$} & \multicolumn{4}{|c|}{$\begin{array}{l}\text { MEAN DISCRETIONARY } \\
\text { ACCRUALS }\end{array}$} & \multicolumn{4}{|c|}{$\begin{array}{c}\text { MEAN NON-DISCRETIONARY } \\
\text { ACCRUALS }\end{array}$} \\
\hline & & $\begin{array}{l}\text { Test } \\
\text { Firms }\end{array}$ & $\begin{array}{l}\text { Control } \\
\text { Firms }\end{array}$ & $\begin{array}{l}\text { Test minus } \\
\text { Control }\end{array}$ & t-stat & Test Firms & $\begin{array}{l}\text { Control } \\
\text { Firms }\end{array}$ & $\begin{array}{l}\text { Test } \\
\text { minus } \\
\text { Control }\end{array}$ & t-stat \\
\hline-3 & 638 & $-1.1 \%$ & $-0.2 \%$ & $-0.8 \%$ & $-1.96^{* * *}$ & $-4.5 \%$ & $-4.9 \%$ & $0.3 \%$ & 0.81 \\
\hline-2 & 790 & $-0.4 \%$ & $0.1 \%$ & $-0.4 \%$ & -1.03 & $-5.0 \%$ & $-5.1 \%$ & $0.1 \%$ & 0.26 \\
\hline-1 & 790 & $0.0 \%$ & $0.1 \%$ & $-0.2 \%$ & -0.44 & $-5.1 \%$ & $-5.1 \%$ & $0.1 \%$ & 0.34 \\
\hline 0 & 790 & $0.4 \%$ & $-0.5 \%$ & $0.9 \%$ & $2.14^{* *}$ & $-5.1 \%$ & $-5.1 \%$ & $0.0 \%$ & 0.10 \\
\hline 1 & 790 & $-0.4 \%$ & $0.2 \%$ & $-0.7 \%$ & $-1.67^{*}$ & $-5.2 \%$ & $-5.5 \%$ & $0.3 \%$ & 0.87 \\
\hline 2 & 679 & $-0.8 \%$ & $-0.4 \%$ & $-0.5 \%$ & -1.13 & $-5.4 \%$ & $-5.2 \%$ & $-0.1 \%$ & -0.32 \\
\hline$(-1,0)$ & 1580 & $0.2 \%$ & $-0.2 \%$ & $0.3 \%$ & & $-5.1 \%$ & $-5.1 \%$ & $0.1 \%$ & \\
\hline$(+1,+2)$ & 1469 & $-0.6 \%$ & $0.0 \%$ & $-0.6 \%$ & & $-5.3 \%$ & $-5.4 \%$ & $0.1 \%$ & \\
\hline $\begin{array}{l}\text { Change } \\
\text { (t-stat) }\end{array}$ & & $\begin{array}{l}-0.8 \% \\
(-2.82)^{* * *}\end{array}$ & $\begin{array}{l}0.1 \% \\
(0.41)\end{array}$ & $\begin{array}{l}-0.9 \% \\
(-2.29)^{* *}\end{array}$ & & $\begin{array}{l}-0.2 \% \\
(-1.00)\end{array}$ & $\begin{array}{l}-0.2 \% \\
(-1.27)\end{array}$ & $\begin{array}{l}0.0 \% \\
(0.21)\end{array}$ & \\
\hline
\end{tabular}

Panel B: Impact of Discretionary Accruals on Earnings Performance

\begin{tabular}{|c|c|c|c|c|c|}
\hline YEAR & $\mathrm{N}$ & $\begin{array}{l}\text { Mean Change in Income } \\
\text { before Extra-ordinary Items } \\
\text { (Test minus Control) }\end{array}$ & t-stat & $\begin{array}{c}\text { Mean Change in Income } \\
\text { before Extra-ordinary Items } \\
\text { (excluding discretionary accruals) } \\
\text { (Test minus Control) }\end{array}$ & t-stat \\
\hline-3 & 638 & $0.63 \%$ & 1.46 & $1.48 \%$ & $2.72^{* * * *}$ \\
\hline-2 & 790 & $-0.06 \%$ & -0.14 & $0.36 \%$ & 0.76 \\
\hline-1 & 790 & $0.06 \%$ & 0.15 & $0.23 \%$ & 0.53 \\
\hline 0 & 790 & $1.06 \%$ & $2.49^{* *}$ & $0.20 \%$ & 0.44 \\
\hline 1 & 790 & $-0.73 \%$ & $-1.77^{*}$ & $-0.06 \%$ & -0.14 \\
\hline 2 & 679 & $-0.42 \%$ & -0.93 & $0.05 \%$ & 0.09 \\
\hline
\end{tabular}

The size of option exercises is measured as the proportion of compensation from stock option exercise, averaged across the top 5 highest compensated executives. Abnormally large exercises are identified by examining the ratio of this proportion with the average from the past (up to three years). Firms for which there was a greater than $50 \%$ increase in this ratio are classified as having abnormally large exercises. These firms are matched at the exercise year (year 0 ) to the closest firm in size (measured by market capitalization) in the same industry (2-digit SIC code), belonging to the same return quintile in year -1 , that did not have an abnormally large exercise. Total accruals are the difference between net income before extra-ordinary items and cash flow from operations, scaled by lagged assets. Discretionary accruals are the residual of the cross-sectional performance adjusted Modified Jones model (as in Kothari et al. 2003). t-statistics for the mean differences are from 2 sample t-tests. All firm-years have complete information from years -2 to +1 . Some firm-years do not have information for year -3 or +2 . $\mathrm{N}$ is the number of test firms (and correspondingly, control firms). Panel B presents results for subset of firms with both income information as well as accrual information. The change in net income before extra-ordinary items (Compustat data item \#18) is scaled by beginning total assets.

Significant at ${ }^{* * *} 1 \%$ level $\quad{ }^{* *} 5 \%$ level ${ }^{*} 10 \%$ level using a 2 tailed test 
TABLE 8

Measuring the Impact of Large Grants on the Results

Panel A: Comparison of Grants and Exercises

\begin{tabular}{|c|c|c|c|c|c|c|c|c|c|c|}
\hline \multirow[t]{2}{*}{ YEAR } & \multirow[t]{2}{*}{$\mathrm{N}$} & \multicolumn{3}{|c|}{$\begin{array}{c}\text { MEAN } \\
\text { EXERCISE } \\
\text { (\$million) }\end{array}$} & \multicolumn{3}{|c|}{$\begin{array}{l}\text { MEAN } \\
\text { GRANT } \\
\text { (\$million) }\end{array}$} & \multicolumn{3}{|c|}{$\begin{array}{l}\text { GRANT > EXERCISE } \\
\text { Proportion }(\%)\end{array}$} \\
\hline & & $\begin{array}{l}\text { Test } \\
\text { Firms }\end{array}$ & $\begin{array}{l}\text { Control } \\
\text { Firms }\end{array}$ & $\begin{array}{l}\text { diff } \\
\text { (t-stat) }\end{array}$ & $\begin{array}{l}\text { Test } \\
\text { Firms }\end{array}$ & $\begin{array}{l}\text { Control } \\
\text { Firms }\end{array}$ & $\begin{array}{l}\text { diff } \\
(t-s t a t)\end{array}$ & $\begin{array}{l}\text { Test } \\
\text { Firms }\end{array}$ & $\begin{array}{l}\text { Control } \\
\text { Firms }\end{array}$ & $\begin{array}{l}\text { diff } \\
\text { (t-stat) }\end{array}$ \\
\hline-3 & 668 & 1.10 & 1.75 & $\begin{array}{l}-0.51 \\
(-2.20)\end{array}$ & 3.13 & 1.95 & $\begin{array}{l}0.34 \\
(1.09)\end{array}$ & $44.5 \%$ & $34.6 \%$ & $\begin{array}{l}9.9 \% \\
(4.23)\end{array}$ \\
\hline-2 & 728 & 0.82 & 1.87 & $\begin{array}{l}-1.05 \\
(-2.52)\end{array}$ & 2.68 & 2.00 & $\begin{array}{l}0.69 \\
(2.11)\end{array}$ & $68.4 \%$ & $53.4 \%$ & $\begin{array}{l}15.0 \% \\
(6.16)\end{array}$ \\
\hline-1 & 728 & 1.05 & 1.88 & $\begin{array}{l}-0.83 \\
(-1.59)\end{array}$ & 3.38 & 2.44 & $\begin{array}{l}0.93 \\
(3.32)\end{array}$ & $75.1 \%$ & $64.1 \%$ & $\begin{array}{l}11.0 \% \\
(4.53)\end{array}$ \\
\hline 0 & 728 & 5.40 & 1.47 & $\begin{array}{l}3.93 \\
(7.11)\end{array}$ & 4.90 & 3.52 & $\begin{array}{l}1.39 \\
(3.33)\end{array}$ & $51.2 \%$ & $74.9 \%$ & $\begin{array}{l}-23.6 \% \\
(9.56)\end{array}$ \\
\hline 1 & 728 & 5.24 & 2.57 & $\begin{array}{l}2.67 \\
(4.20)\end{array}$ & 6.33 & 4.44 & $\begin{array}{l}1.89 \\
(3.21)\end{array}$ & $62.6 \%$ & $65.0 \%$ & $\begin{array}{l}-2.3 \% \\
(-0.91)\end{array}$ \\
\hline 2 & 722 & 5.38 & 4.51 & $\begin{array}{l}0.93 \\
(0.81)\end{array}$ & 6.87 & 4.68 & $\begin{array}{l}1.82 \\
(2.72)\end{array}$ & $58.6 \%$ & $54.8 \%$ & $\begin{array}{l}3.7 \% \\
(1.56)\end{array}$ \\
\hline
\end{tabular}

Panel B: Subsample with only Low Grant Observations (GRANT < EXERCISE in Year 0)

\begin{tabular}{|c|c|c|c|c|c|c|}
\hline YEAR & $\mathrm{N}$ & $\begin{array}{l}\text { Change in Operating Income: } \\
\text { Test - Control } \\
\text { (t-stat) }\end{array}$ & $\mathrm{N}$ & $\begin{array}{l}\text { Stock Returns: } \\
\text { Test - Control } \\
\text { (t-stat) }\end{array}$ & $\mathrm{N}$ & $\begin{array}{l}\text { Discretionary } \\
\text { Accruals: } \\
\text { Test - Control } \\
\text { (t-stat) }\end{array}$ \\
\hline-3 & 443 & $\begin{array}{l}0.4 \% \\
(1.30)\end{array}$ & 584 & $\begin{array}{l}3.9 \% \\
(1.16)\end{array}$ & 325 & $\begin{array}{l}-0.7 \% \\
(-1.55)\end{array}$ \\
\hline-2 & 524 & $\begin{array}{l}0.9 \% \\
(2.95)^{* * *}\end{array}$ & 675 & $\begin{array}{l}13.7 \% \\
(4.03)^{* * * *}\end{array}$ & 399 & $\begin{array}{l}-0.5 \% \\
(-1.15)\end{array}$ \\
\hline-1 & 524 & $\begin{array}{l}0.8 \% \\
(2.88)^{* * *}\end{array}$ & 675 & $\begin{array}{l}-1.8 \% \\
(-0.55)\end{array}$ & 399 & $\begin{array}{l}-0.9 \% \\
(-2.19)^{* *}\end{array}$ \\
\hline 0 & 524 & $\begin{array}{l}1.1 \% \\
(4.24)^{* * *}\end{array}$ & 675 & $\begin{array}{l}12.8 \% \\
(2.85)^{* * *}\end{array}$ & 399 & $\begin{array}{l}0.9 \% \\
(2.05)^{* *}\end{array}$ \\
\hline 1 & 524 & $\begin{array}{l}0.3 \% \\
(-1.10)\end{array}$ & 675 & $\begin{array}{l}-12.3 \% \\
(-3.68)^{* * *}\end{array}$ & 399 & $\begin{array}{l}-0.5 \% \\
(-1.20)\end{array}$ \\
\hline 2 & 446 & $\begin{array}{l}-0.5 \% \\
(-1.49)\end{array}$ & 585 & $\begin{array}{l}-2.3 \% \\
(-0.64)\end{array}$ & 340 & $\begin{array}{l}-1.1 \% \\
(-2.62)^{* * *}\end{array}$ \\
\hline
\end{tabular}


Panel C: Subsample with only High Grant Observations (GRANT $\geq$ EXERCISE in Year 0)

\begin{tabular}{l|ll|ll|ll}
\hline YEAR & $\mathrm{N}$ & $\begin{array}{l}\text { Change in } \\
\text { Operating Income: } \\
\text { Test - Control } \\
\text { (t-stat) }\end{array}$ & $\mathrm{N}$ & $\begin{array}{l}\text { Stock Returns: } \\
\text { Test - Control } \\
(\mathrm{t}-\mathrm{stat})\end{array}$ & $\mathrm{N}$ & $\begin{array}{l}\text { Discretionary } \\
\text { Accruals: } \\
\text { Test - Control } \\
\text { (t-stat) }\end{array}$ \\
\hline-3 & 439 & $\begin{array}{l}0.2 \% \\
(0.63)\end{array}$ & 563 & $\begin{array}{l}-3.9 \% \\
(-1.32)\end{array}$ & 313 & $\begin{array}{l}-0.9 \% \\
(-1.99)^{* *}\end{array}$ \\
-2 & 521 & $\begin{array}{l}-0.1 \% \\
(0.28)\end{array}$ & 647 & $\begin{array}{l}6.0 \% \\
(1.93)^{*}\end{array}$ & 391 & $\begin{array}{l}-0.3 \% \\
(-0.69)\end{array}$ \\
-1 & 521 & $\begin{array}{l}0.2 \% \\
(0.61)\end{array}$ & 647 & $\begin{array}{l}0.9 \% \\
(0.44)\end{array}$ & 391 & $\begin{array}{l}0.5 \% \\
(1.22)\end{array}$ \\
0 & 521 & $\begin{array}{l}-0.3 \% \\
(-0.99)\end{array}$ & 647 & $\begin{array}{l}5.5 \% \\
(1.30)\end{array}$ & 391 & $\begin{array}{l}0.9 \% \\
(1.98)^{* *}\end{array}$ \\
1 & 521 & $\begin{array}{l}-0.1 \% \\
(-0.25)\end{array}$ & 647 & $\begin{array}{l}-10.1 \% \\
(-2.61)^{* * *}\end{array}$ & 391 & $\begin{array}{l}-0.9 \% \\
(-1.93)^{*}\end{array}$ \\
2 & 442 & $\begin{array}{l}-0.3 \% \\
(-0.87)\end{array}$ & 564 & $\begin{array}{l}-2.9 \% \\
(-0.63)\end{array}$ & 339 & $0.1 \%$ \\
& & & & & \\
\hline
\end{tabular}

Panel A provides descriptive statistics on the grants and exercises for test firms and control firms. Stock Option Grants are measured as the disclosed value of option grants as reported by firms in their SFAS No. 123 disclosures aggregated for the top 5 compensated employees. Stock Option Exercises are measured as the net value realized by executives from exercising options, i.e. the difference between exercise price and closing stock price on the day of the exercise, aggregated for the top 5 compensated employees. Panel B excludes firms that had greater stock option grants than stock option exercises and repeats tests from tables 4, 5 and 7. t-statistics for the mean differences are from 2 sample t-tests. All firm-years have complete information from years -2 to +1 . Some firm-years do not have information for year -3 or +2 . $\mathrm{N}$ is the number of test firms (and correspondingly, control firms).

Significant at $\quad{ }^{* * *} 1 \%$ level $\quad{ }^{* *} 5 \%$ level $\quad{ }^{*} 10 \%$ level using a 2 tailed test 